\title{
Frictional properties and microstructural evolution of dry and wet calcite-dolomite gouges
}

\author{
Matteo Demurtas ${ }^{1,2}$, Steven A.F. Smith ${ }^{3}$, Elena Spagnuolo ${ }^{4}$, and Giulio Di Toro ${ }^{4,5}$ \\ ${ }^{1}$ Physics of Geological Processes, The Njord Centre, Department of Geosciences, University of Oslo, Oslo 0356, Norway \\ ${ }^{2}$ Department of Earth Science, University of Bergen, Bergen 5020, Norway \\ ${ }^{3}$ Department of Geology, University of Otago, Dunedin 9054, New Zealand \\ ${ }^{4}$ Istituto Nazionale di Geofisica e Vulcanologia (INGV), Rome 00143, Italy \\ ${ }^{5}$ Dipartimento di Geoscienze, Università degli Studi di Padova, 35131 Padua, Italy
}

Correspondence: Matteo Demurtas (matteo.demurtas@uib.no)

Received: 5 October 2020 - Discussion started: 8 October 2020

Revised: 22 January 2021 - Accepted: 31 January 2021 - Published: 5 March 2021

\begin{abstract}
Calcite and dolomite are the two most common minerals in carbonate-bearing faults and shear zones. Motivated by observations of exhumed seismogenic faults in the Italian Central Apennines, we used a rotary-shear apparatus to investigate the frictional and microstructural evolution of ca. $3 \mathrm{~mm}$ thick gouge layers consisting of $50 \mathrm{wt} \%$ calcite and $50 \mathrm{wt} \%$ dolomite. The gouges were sheared at a range of slip rates $\left(30 \mu \mathrm{m} \mathrm{s}^{-1}-1 \mathrm{~m} \mathrm{~s}^{-1}\right)$, displacements $(0.05-0.4 \mathrm{~m})$, and a normal load of $17.5 \mathrm{MPa}$ under both room-humidity and water-dampened conditions. The frictional behaviour and microstructural evolution of the gouges were strongly influenced by the presence of water. At room humidity, slip strengthening was observed up to slip rates of $0.01 \mathrm{~m} \mathrm{~s}^{-1}$, which was associated with gouge dilation and the development of a 500-900 $\mu \mathrm{m}$ wide slip zone cut by Y-, R-, and $\mathrm{R}_{1}$-shear bands. Above a slip rate of $0.1 \mathrm{~m} \mathrm{~s}^{-1}$, dynamic weakening accompanied the development of a localised $<100 \mu \mathrm{m}$ thick principal slip zone preserving microstructural evidence for calcite recrystallisation and dolomite decarbonation, while the bulk gouges developed a well-defined foliation consisting of organised domains of heavily fractured calcite and dolomite. In water-dampened conditions, evidence of gouge fluidisation within a fine-grained principal slip zone was observed at a range of slip rates from $30 \mu \mathrm{m} \mathrm{s}^{-1}$ to $0.1 \mathrm{~m} \mathrm{~s}^{-1}$, suggesting that caution is needed when relating fluidisation textures to seismic slip in natural fault zones. Dynamic weakening in water-dampened conditions was observed at $1 \mathrm{~m} \mathrm{~s}^{-1}$, where the principal slip zone was characterised by patches of recrystallised calcite. However, local
\end{abstract}

fragmentation and reworking of recrystallised calcite suggests a cyclic process involving formation and destruction of a heterogeneous slip zone. Our microstructural data show that development of well-defined gouge foliation under the tested experimental conditions is limited to high velocities $\left(>0.1 \mathrm{~m} \mathrm{~s}^{-1}\right)$ and room humidity, supporting the notion that some foliated gouges and cataclasites may form during seismic slip in natural carbonate-bearing faults.

\section{Introduction}

Calcite and dolomite are the most common minerals in carbonate-bearing faults and shear zones (e.g. Busch and van der Pluijm, 1995; Snoke et al., 1998; Bestmann et al., 2000; De Paola et al., 2006; Molli et al., 2010; Tesei et al., 2014; Fondriest et al., 2015, 2020; Delle Piane et al., 2017). In some cases, the distribution and timing of dolomitisation plays an important role in controlling strain localisation. For example, ductile deformation along the Naukluft nappe complex in central Namibia was distributed within a sequence of calcite mylonites, but the main Naukluft Fault localised within dolomitised layers (Viola et al., 2006; Miller et al., 2008).

Although similar in composition, the rheology, deformation mechanisms, and frictional behaviour of calcite and dolomite show important differences. Deformation of calcite has been widely investigated using microstructural analysis (Kennedy and Logan, 1997; Kennedy and White, 2001; Liu et al., 2002; Bestmann et al., 2006; Molli et al., 2011) 
and laboratory experiments over a wide range of conditions, which includes experiments performed at relatively low strain rates $\left(<10^{-2} \mathrm{~s}^{-1}\right)$, high temperatures $\left(>500^{\circ} \mathrm{C}\right)$, and high pressures (> 100 MPa) (e.g. Rutter, 1972; Schmid et al., 1980, 1987; De Bresser and Spiers, 1990; Rutter, 1995; Paterson and Olgaard, 2000), as well as experiments performed at relatively high shear rates $\left(>1 \mu \mathrm{m} \mathrm{s}^{-1}\right)$, low temperatures $\left(<150^{\circ} \mathrm{C}\right)$, and low pressures $(<50 \mathrm{MPa})$ (Smith et al., 2013, 2015; Verberne et al., 2014; De Paola et al., 2015; Rempe et al., 2017; Tesei et al., 2017). Comparatively, the rheology and frictional behaviour of dolomite is relatively poorly understood (e.g. Barber et al., 1981; Weeks and Tullis, 1985). Recently, the importance of dolomite as a fault and shear zone material in sedimentary and metamorphic settings has been emphasised in a number of experimental studies (Austin and Kennedy, 2005; Delle Piane et al., 2007, 2008; Davis et al., 2008; De Paola et al., 2011a, b; Boneh et al., 2013; Fondriest et al., 2013; Holyoke et al., 2014; Green et al., 2015). At low strain rates, dolomite is brittle up to ca. $700^{\circ} \mathrm{C}$ (Kushnir et al., 2015), while calcite can undergo recrystallisation at temperatures as low as $150-200{ }^{\circ} \mathrm{C}$ (Kennedy and White, 2001). This pronounced difference in deformation style under similar ambient conditions may significantly influence the rheology of faults and shear zones in which the two phases co-exist (Oesterling et al., 2007; Kushnir et al., 2015).

Only a few experimental studies have investigated the mechanical behaviour and microstructural evolution of calcitedolomite mixtures. Experiments have been performed to study the rheological behaviour of mixtures at relatively high pressures and temperatures (e.g. torsion experiments; Delle Piane et al., 2009; Kushnir et al., 2015), as well as the frictional behaviour of mixtures at room temperature over a wide range of strain rates (e.g. room temperature rotary-shear experiments; Mitchell et al., 2015; Smith et al., 2017; Demurtas et al., 2019a, b). In torsion experiments (confining pressures up to $300 \mathrm{MPa}$, temperatures of $700-800^{\circ} \mathrm{C}$, shear strain rate $\dot{\gamma}=1-3 \times 10^{-4} \mathrm{~s}^{-1}$, and finite shear strain $\gamma<11$ ), minor quantities of dolomite (e.g. $25 \mathrm{wt} \%$ ) in a sintered calcite-rich sample significantly increased the yield strength with respect to pure calcite samples (Kushnir et al., 2015). Under such experimental conditions, two main deformation mechanisms were observed: brittle fracturing in the dolomite grains and ductile flow in calcite, possibly as a result of grain boundary sliding assisted by diffusion creep and dislocation glide (Kushnir et al., 2015). Strain hardening observed in these experiments was interpreted to be due to dolomite grains interrupting more continuous calcite-rich layers and acting as stress concentrators. Brittle failure of dolomite grains eventually allowed the calcite-rich layers to become continuous and to continue deforming by superplastic flow (Kushnir et al., 2015). Although these torsion experiments were performed under significantly elevated temperatures and pressures compared to the experiments in this paper, the results suggest that the occurrence of dolomite in calcite aggregates can influence the mechanical behaviour during deformation.

Mitchell et al. (2015) and Smith et al. (2017) studied the frictional behaviour and microstructural evolution of gouge mixtures $(50 \mathrm{wt} \%$ dolomite and $50 \mathrm{wt} \%$ calcite) deformed at low normal stresses $\left(\sigma_{n} \leq 17.5 \mathrm{MPa}\right)$, high slip rates $(V \geq$ $\left.0.01 \mathrm{~m} \mathrm{~s}^{-1}\right)$, and large displacements $(d=0.03-3 \mathrm{~m})$, with the aim of reproducing conditions encountered at the base of fast-moving landslides and during the seismic cycle in shallow crustal faults. At a slip velocity of $1 \mathrm{~m} \mathrm{~s}^{-1}$, dynamic weakening was associated with grain size reduction and decarbonation of dolomite within the experimental principal slip zone and in the nearby bulk gouge. During the early stages of these high-velocity experiments and prior to the onset of dynamic weakening, a well-defined foliation developed within the bulk gouge mixtures due to brittle fracturing of calcite and dolomite accompanied by shearing of the fractured grains in to compositional bands (Mitchell et al., 2015; Smith et al., 2017). These observations indicate that some natural examples of foliated gouges and cataclasites could form during coseismic shearing (Smith et al., 2017), challenging the common interpretation that fault rock foliations result from slow aseismic creep (e.g. Rutter et al., 1986; Chester and Chester, 1998; Lin, 2001; Jefferies et al., 2006). Additionally, Demurtas et al. (2019a) documented the presence of a well-defined crystallographic preferred orientation (CPO) in calcite-dolomite gouges and interpreted the CPO to result from "brittle" processes involving grain rotation and preferential fracturing along calcite cleavage planes during granular flow at room temperature. Instead, in regions of the mixed gouge layers that experienced substantial frictional heating during high-velocity slip (i.e. within the principal slip zone), transmission Kikuchi diffraction analysis suggested that nanogranular aggregates deformed via a combination of grain-size-sensitive (grains $<800 \mathrm{~nm}$ ) and grainsize-insensitive (grains $>800 \mathrm{~nm}$ ) plastic creep (Demurtas et al., 2019b).

The experimental work summarised above indicates that a diverse range of microstructures can form in calcitedolomite gouges as a result of both brittle and plastic processes and that the prevailing microstructures depend on ambient conditions, strain history, and proximity to zones of shear localisation and heating. Potentially, this range of microstructures could be recognised in natural gouges and cataclasites, which would provide important insights into the evolution of slip conditions during the seismic cycle in carbonate-bearing faults. However, to successfully apply the experimental findings to natural fault zones, a more complete picture of microstructural diversity and its dependence on deformation conditions is required. In this context, the aim of this paper is to provide (i) a more comprehensive description of the frictional and microstructural evolution of mixed calcite-dolomite gouges deformed at sub-seismic to seismic slip rates and (ii) an updated framework for the interpretation 
of microstructures found in natural calcite- and dolomitebearing faults.

\section{Methods}

\subsection{Starting materials}

Synthetic gouges were prepared by mixing $50 \mathrm{wt} \%$ calcite and $50 \mathrm{wt} \%$ dolomite, as previously described in Demurtas et al. (2019a). The calcite-dolomite ratio in the experimental mixtures is similar to that found in natural fault gouges and cataclasites from the Vado di Corno Fault Zone (VCFZ, Italian Central Apennines; Demurtas et al., 2016) and used in previous experimental studies (Smith et al., 2017). The calcite gouge was derived by crushing Carrara marble with a modal composition of $98.8 \mathrm{wt} \%$ calcite and $<1 \mathrm{wt} \%$ dolomite and muscovite (see Supplement). The dolomite gouge was derived by crushing dolomitised portions of the Calcare Massiccio Formation from the VCFZ (Demurtas et al., 2016). The crushed gouges were passed through a $250 \mu \mathrm{m}$ sieve and then mixed together by slow tumbling for ca. $30 \mathrm{~min}$. Two batches of gouge were prepared (CDM1, calcite $=47.2 \mathrm{wt} \%$ and dolomite $=52.8 \mathrm{wt} \%$; CDM2, calcite $=42.9 \mathrm{wt} \%$ and dolomite $=57.1 \mathrm{wt} \%$ ).

\subsection{Experimental setup and deformation conditions}

A total of 19 experiments were performed at slip rates from $30 \mu \mathrm{m} \mathrm{s}^{-1}$ to $1 \mathrm{~m} \mathrm{~s}^{-1}$ with SHIVA (Slow- to HIgh-Velocity rotary-shear friction Apparatus) at the Istituto Nazionale di Geofisica e Vulcanologia in Rome (Di Toro et al., 2010; Niemeijer et al., 2011) (Table 1). The gouges were deformed inside a metal holder specifically designed for incohesive materials (Fig. 1; Smith et al., 2013, 2015). The thickness of the gouge layers at the start of the experiments was ca. $3 \mathrm{~mm}$. Horizontal displacements of the axial column were sampled at $2.5 \mathrm{~Hz}-25 \mathrm{kHz}$, and measured using a direct current differential transformer (DCDT, $50 \mathrm{~mm}$ range and ca. $50 \mu \mathrm{m}$ resolution) and a linear variable differential transformer (LVDT, $3 \mathrm{~mm}$ range and ca. $0.03 \mu \mathrm{m}$ resolution). Further details of the data acquisition system and the location and calibration of the load cells, detectors, and devices are found in Niemeijer et al. (2011) and Smith et al. (2013).

Measurements of room humidity and room temperature were collected at a distance of $<1 \mathrm{~cm}$ from the gouge holder before and during the experiments (Fig. 1a). Temperature variations during deformation were measured at an acquisition rate of $2.5 \mathrm{~Hz}$ using four K-type thermocouples (nickelalumel) installed on the stationary side of the gouge holder (Fig. 1a-b; Demurtas et al., 2019a). One thermocouple was positioned ca. $200 \mu \mathrm{m}$ from the gouge layer (Fig. 1b). The other three thermocouples were located in the sample holder and stationary column to detect temperature variations due to heat conduction through the gouge holder and apparatus (Fig. 1a). $\mathrm{CO}_{2}$ emissions were monitored using an Om-
niStar ${ }^{\mathrm{TM}}$ GSD $301 \mathrm{O}$ mass spectrometer designed for gas analysis at atmospheric pressure.

Experiments were performed under both room-humidity and water-dampened conditions at a constant normal stress of $17.5 \pm 0.1 \mathrm{MPa}$ (Table 1), the same normal stress used in some previous SHIVA experiments conducted on calcite, dolomite, and calcite-dolomite gouges (Fondriest et al., 2013; Smith et al., 2015, 2017). Room humidity varied between $41 \%$ and $62 \%$, and room temperature varied between 19 and $22^{\circ} \mathrm{C}$. In water-dampened conditions, ca. $2 \mathrm{~mL}$ of deionised water was added to the top of the gouge layer using a pipette before the gouge holder was positioned in the apparatus. Experiment s1327 was performed using a specially designed water bath that ensured saturation within the gouge layer during this long-duration experiment (Supplement). The gouge holder used in the experiments did not allow us to measure pore-fluid pressure during water-dampened experiments. Experiments were performed at target slip rates ranging from $30 \mu \mathrm{m} \mathrm{s}^{-1}$ to $1 \mathrm{~m} \mathrm{~s}^{-1}$, with acceleration and deceleration of $6 \mathrm{~m} \mathrm{~s}^{-2}$. Total displacements ranged from 0.05 to $0.4 \mathrm{~m}$. Two compaction experiments were performed by applying a normal stress of $17.5 \mathrm{MPa}$ for 300 s (i.e. static load experiments in Table 1) and used as references for the microstructure of the starting materials.

\subsection{Analytical techniques}

After each experiment, the entire gouge layer was recovered and impregnated in low-viscosity epoxy (Araldite 2020) for microstructural analysis. Polished thin sections were cut perpendicular to the gouge layer and sub-parallel (i.e. tangential cut) to the slip direction (Fig. 1d). Microstructural analysis was performed with a Zeiss Sigma VP field-emission scanning electron microscope (SEM) at the Otago Micro and Nanoscale Imaging facility (OMNI; University of Otago. Acquisition conditions for backscattered electron images: accelerating voltage $15 \mathrm{kV}$, working distance 6-7 mm). Energydispersive X-ray spectroscopy (EDS) in the SEM was used to produce element maps showing the distribution of calcium and magnesium, which highlights the distribution of calcite and dolomite. Crystallographic orientation data from calcite were acquired by electron backscatter diffraction (EBSD) on SYTON-polished thin sections. Data were collected with a Nordlys EBSD camera from Oxford Instruments and processed using AZtec software (Oxford Instruments). Mineralogical changes that occurred during the experiments were determined by semi-quantitative X-ray powder diffraction (XRPD) conducted in the Department of Geoscience, University of Padua. The XRPD analyses were performed on both the bulk gouges and on small intact chips of the localised slip surfaces that formed in the experiments. 
Table 1. Experiments reported in this study.

\begin{tabular}{|c|c|c|c|c|c|c|}
\hline & Experiment & $\begin{array}{l}\text { Experimental } \\
\text { conditions }\end{array}$ & $\begin{array}{l}\text { Target slip rate } \\
\mathrm{m} \mathrm{s}^{-1}\end{array}$ & $\begin{array}{c}\text { Displacement } \\
\mathrm{m}\end{array}$ & $\begin{array}{c}\text { Normal stress } \\
\mathrm{MPa}\end{array}$ & $\begin{array}{c}\text { Mixture } \\
\text { batch }\end{array}$ \\
\hline & s1322 & Room humidity & 0.00003 & 0.1 & 17.5 & CDM2 \\
\hline & s1210 & Room humidity & 0.00003 & 0.4 & 17.5 & CDM1 \\
\hline & s1211 & Room humidity & 0.0001 & 0.4 & 17.5 & CDM1 \\
\hline & s1323 & Room humidity & 0.001 & 0.1 & 17.5 & CDM2 \\
\hline & s1212 & Room humidity & 0.001 & 0.4 & 17.5 & CDM1 \\
\hline & s1217 & Room humidity & 0.01 & 0.4 & 17.5 & CDM1 \\
\hline & s1218 & Room humidity & 0.1 & 0.4 & 17.5 & CDM1 \\
\hline & s1221 & Room humidity & 1 & 0.4 & 17.5 & CDM1 \\
\hline & s1327 & Water dampened & 0.00003 & 0.05 & 17.5 & CDM2 \\
\hline & s1329 & Water dampened & 0.00003 & 0.1 & 17.5 & CDM2 \\
\hline & s1328 & Water dampened & 0.00003 & 0.2 & 17.5 & CDM2 \\
\hline & s1214 & Water dampened & 0.00003 & 0.4 & 17.5 & CDM1 \\
\hline & s1330 & Water dampened & 0.00003 & 0.4 & 17.5 & CDM2 \\
\hline & s1215 & Water dampened & 0.0001 & 0.4 & 17.5 & CDM1 \\
\hline & s1213 & Water dampened & 0.001 & 0.4 & 17.5 & CDM1 \\
\hline & s1219 & Water dampened & 0.01 & 0.4 & 17.5 & CDM1 \\
\hline & s1220 & Water dampened & 0.1 & 0.4 & 17.5 & CDM1 \\
\hline & s1222 & Water dampened & 1 & 0.4 & 17.5 & CDM1 \\
\hline \multirow[t]{2}{*}{ Static load } & sld & Room humidity & & & 17.5 & CDM1 \\
\hline & slw & Water dampened & & & 17.5 & CDM2 \\
\hline
\end{tabular}

\section{Results}

\subsection{Friction evolution with slip and slip rate}

The evolution of the effective friction coefficient $(\mu)$ with slip and slip rate was influenced by the availability of water during deformation (Figs. 2, 3). In room-humidity conditions and slip rates of $\leq 0.01 \mathrm{~m} \mathrm{~s}^{-1}$, the calcite-dolomite mixtures showed a progressive increase of $\mu$ (slip-strengthening behaviour) up to $0.75-0.80$ (measured between 0.15 and $0.35 \mathrm{~m}$ of slip) following an initial peak fiction $\left(\mu_{\text {peak }}\right)$ of $0.64-0.71$ (Figs. 2, 3). At a slip rate of $0.1 \mathrm{~m} \mathrm{~s}^{-1}$, a substantial decrease of $\mu$ was observed (slip weakening behaviour to steady-state $\mu_{\mathrm{ss}}$ of $0.55 \pm 0.01$ ) following a prolonged initial strengthening phase (ca. $0.062 \mathrm{~m}$ ) that reached $\mu_{\text {peak }}$ of 0.68 (Fig. 2b). Significant dynamic weakening was observed at a slip rate of $1 \mathrm{~m} \mathrm{~s}^{-1}$, following a short initial strengthening phase (lasting ca. $0.005 \mathrm{~m}$ ) that was followed by a steady state of $\mu_{\mathrm{ss}}$ of 0.28 (Figs. 2a, 3b). A re-strengthening phase (final $\mu$ up to ca. 0.56) was observed during deceleration of the rotary column.

In water-dampened conditions, the gouge mixtures showed a similar evolution of friction at slip rates $\leq 0.1 \mathrm{~m} \mathrm{~s}^{-1}$, characterised by slight slip strengthening to slip neutral behaviour (Fig. 2c). Notably, $\mu_{\text {peak }}$ and $\mu_{\mathrm{ss}}$ were lower than in room-humidity experiments, with $\mu_{\text {peak }}=0.61-0.64$ and $\mu_{\mathrm{ss}}=0.62-0.70$, respectively (Fig. 3). At a slip rate of $1 \mathrm{~m} \mathrm{~s}^{-1}$, the initial strengthening phase was much shorter than in room-humidity conditions (ca.
$0.003 \mathrm{~m}$ ), and dynamic weakening resulted in $\mu_{\mathrm{ss}}$ of $0.31 \pm 0.02$. Re-strengthening was also observed during deceleration, with an increase in $\mu$ up to 0.57 .

\subsection{Gouge thickness evolution with slip rate}

No significant gouge loss was observed during the experiments, with the exception of those performed at $V=$ $0.1 \mathrm{~m} \mathrm{~s}^{-1}$ discussed below. Therefore, the evolution of axial displacement is interpreted to result from changes in gouge layer thickness due to dilation and compaction. In roomhumidity conditions, the evolution of gouge layer thickness depends on slip rate (Fig. 4a). At $V \leq 0.001 \mathrm{~m} \mathrm{~s}^{-1}$, the gouge layers show a three-stage evolution: (i) initial compaction of ca. $90-120 \mu \mathrm{m}$ at the onset of sliding, (ii) dilation of ca. 50-70 $\mu \mathrm{m}$ during the slip strengthening phase, and (iii) approximately constant thickness once the steady-state friction coefficient is reached. Overall compaction of ca. 30$60 \mu \mathrm{m}$ is recorded. At $V=0.01 \mathrm{~m} \mathrm{~s}^{-1}$, after a short lived dilatancy phase (inset in Fig. 4a), initial compaction of $100 \mu \mathrm{m}$ is followed by approximately constant thickness (Fig. 4a). At higher slip rates $\left(V \geq 0.1 \mathrm{~m} \mathrm{~s}^{-1}\right)$, continuous compaction was observed throughout the experiments (up to ca. $300 \mu \mathrm{m}$ of axial shortening at $V=1 \mathrm{~m} \mathrm{~s}^{-1}$ ), and compaction rate increased with slip rate (Fig. 4a).

Under water-dampened conditions, the gouge mixtures exhibit a similar evolution of thickness irrespective of slip rate (Fig. 4b). Compaction was initially rapid in the first few centimetres of sliding and then reached an approximately con- 

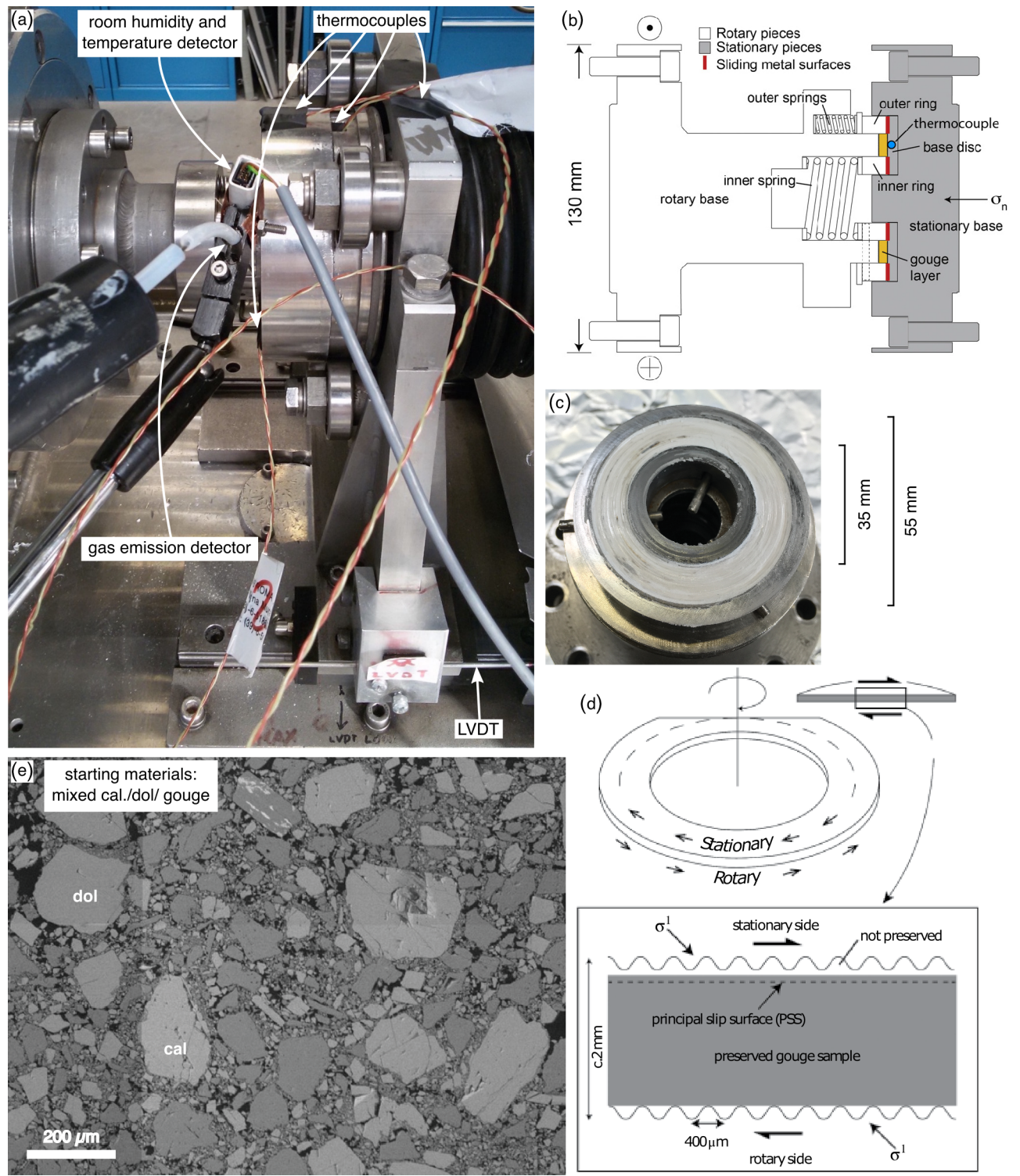

Figure 1. Rotary-shear experimental setup. (a) Detectors in the sample chamber. Gas emission, humidity, and temperature detectors were placed at $<1 \mathrm{~cm}$ from the sample holder. Four thermocouples were placed on the stationary side at increasing distances from the gouge layer. Note that the position of the thermocouple nearest to the gouge layer is not visible here and is illustrated in (b). (b) Diagram of the gouge holder with the location of the thermocouple nearest to the gouge layer (modified following Smith et al., 2015). (c) Sample appearance post-deformation with mirror-like slip surface formed in an experiment performed at $V=0.1 \mathrm{~m} \mathrm{~s}^{-1}$. (d) Diagram showing the location of the recovered and analysed gouge layer after the experiment (following Smith et al., 2017). (e) SEM backscattered electron (SEM-BSE) image of the starting material after applying $17.5 \mathrm{MPa}$ for $300 \mathrm{~s}$.

stant compaction rate that was similar in all experiments. Total compaction of ca. 200-250 $\mu$ m was recorded (Fig. 4b).

\subsection{Temperature evolution and $\mathrm{CO}_{2}$ emissions}

Figure 5a shows maximum temperatures measured by the thermocouple located closest to the gouge layers (Fig. 1b; Demurtas et al., 2019a, described temperature evolution with slip). The maximum temperature $\left(621^{\circ} \mathrm{C}\right)$ was achieved in experiment s1221 performed under room-humidity condi- tions at $V=1 \mathrm{~m} \mathrm{~s}^{-1}$ (Fig. 5a). For the same slip rate and normal stress but in water-dampened conditions, the maximum temperature was $210^{\circ} \mathrm{C}$ (Fig. 5a). Temperature increases were detected in all experiments at slip rates $\geq 0.01 \mathrm{~m} \mathrm{~s}^{-1}$, and the maximum temperature increased with increasing slip rate (Fig. 5a).

Because the OmniStar mass spectrometer acquisition system used to detect $\mathrm{CO}_{2}$ emissions is independent from the control system on SHIVA, $\mathrm{CO}_{2}$ emissions are plotted simply 

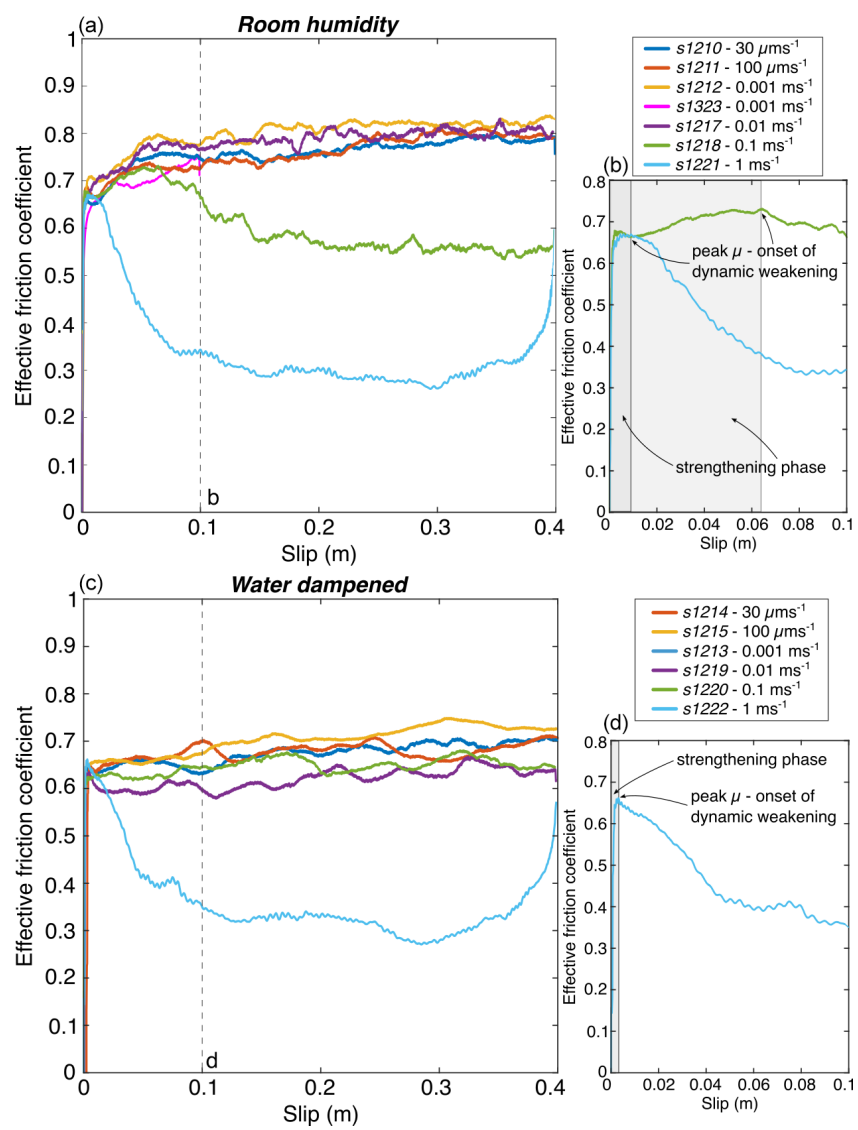

Figure 2. Effective friction coefficient in mixed calcite-dolomite gouges. (a, c) Effective friction coefficient versus slip under roomhumidity and water-dampened conditions. $(\mathbf{c}, \mathbf{d})$ Detail of effective friction coefficient versus slip in the first $0.1 \mathrm{~m}$ of slip in experiments where slip weakening was observed.

against the time (in seconds) at which the mass spectrometer was started, which is variable for each experiment (Fig. 5b). $\mathrm{CO}_{2}$ emissions above ambient levels were only detected in experiments at slip rates $\geq 0.1 \mathrm{~m} \mathrm{~s}^{-1}$ (Fig. 5b). Because the mass spectrometer was not calibrated and the sample holder was open to the laboratory, the data can only be used in a qualitative way. In room-humidity conditions, the intensity of the $\mathrm{CO}_{2}$ peak was significantly higher at $1 \mathrm{~m} \mathrm{~s}^{-1}$ than at $0.1 \mathrm{~m} \mathrm{~s}^{-1}$. In water-dampened conditions, the $\mathrm{CO}_{2}$ peaks were substantially smaller than at equivalent room-humidity conditions.

\subsection{Mineralogy of deformed gouges}

Compared to the starting materials, no mineralogical changes were detected in any of the deformed bulk gouges (see Supplement). In room-humidity experiment $\mathrm{s} 1210\left(30 \mu \mathrm{m} \mathrm{s}^{-1}\right)$, a slight broadening of the main peak for calcite was observed (Fig. 6a), and this was also observed to a lesser degree for dolomite. XRPD analysis of cohesive chips recovered from the slip surface of water-dampened experiment s1214 $\left(V=30 \mu \mathrm{m} \mathrm{s}^{-1}\right)$ indicates the presence of aragonite (Fig. 6b). At $V=1 \mathrm{~m} \mathrm{~s}^{-1}$ and room-humidity conditions (experiment s1221), the recovered slip surface was composed of dolomite, $\mathrm{Mg}$ calcite, and periclase ( $\mathrm{MgO}$ ) (Fig. 6c). Mg calcite and periclase are two of the main products of dolomite decarbonation that starts at ca. $550^{\circ} \mathrm{C}\left(\mathrm{MgCa}\left(\mathrm{CO}_{3}\right)_{2} \rightarrow\right.$ $\mathrm{MgO}+(\mathrm{Ca}, \mathrm{Mg}) \mathrm{CO}_{3}+\mathrm{CO}_{2}$; Samtani et al., 2002; De Paola et al., 2011a, b).

\subsection{Microstructures of deformed gouge layers}

\subsubsection{Microstructures of room-humidity experiments}

At slip rates $\leq 0.01 \mathrm{~m} \mathrm{~s}^{-1}$, gouges were characterised by the development of a 500-900 $\mu \mathrm{m}$ thick slip zone (Figs. 7a and 8), consisting of a fine-grained matrix (grain size ca. $1 \mu \mathrm{m}$ ) containing subrounded grains of dolomite ca. $5-10 \mu \mathrm{m}$ in size (Fig. 7b). The slip zone contains sub-parallel, 10-30 $\mu \mathrm{m}$ thick, Y-, R-, and $\mathrm{R}_{1}$-type shear bands (using the terminology of Logan et al., 1979, Fig. 7a, c). Each individual shear band is associated with a very fine-grained matrix (grain size $<1 \mu \mathrm{m}$ ) composed of calcite and dolomite. The presence of multiple interlinked shear bands contributes to a weak foliation within the slip zone that lies sub-parallel to gouge layer boundaries (Fig. 7a). Y, R, and most notably $\mathrm{R}_{1}$ shears gradually decrease in abundance with increasing slip rate. The transition from fine-grained slip zone to highly fractured bulk gouge is typically well defined (see the upper part of Fig. 7d). The bulk gouge shows widespread cataclasis and intragranular fracturing, which is focussed preferentially into calcite grains (Smith et al., 2017; Demurtas et al., 2019a). Fractures that cut relatively large grains of calcite in the bulk gouge often exploit cleavage planes (e.g. Fig. 7d; Smith et al., 2017; Demurtas et al., 2019a).

At a slip rate of $0.1 \mathrm{~m} \mathrm{~s}^{-1}$, the bulk gouge develops a weak foliation defined by compositional banding of heavily fractured calcite- and dolomite-rich domains, which lie adjacent to a localised principal slip zone ca. $110 \mu \mathrm{m}$ thick (Fig. 7e). The foliation is inclined $25-30^{\circ}$ to the principal slip surface and appears to form by disaggregation and shearing of originally intact calcite and dolomite grains (Fig. 7e). Locally, the principal slip surface is associated with discontinuous lensshaped patches (up to 15-20 $\mu \mathrm{m}$ thick) of calcite with irregular boundaries and negligible porosity (Fig. 7f).

In experiments conducted at $1 \mathrm{~m} \mathrm{~s}^{-1}$, the bulk gouges developed a well-defined foliation across most of the thickness of the layers (Fig. 9; Smith et al., 2017; Demurtas et al., 2019a, b). The foliation is defined by alternating calciteand dolomite-rich domains inclined at ca. $40^{\circ}$ to the principal slip surface (Fig. 9a-b), which become progressively rotated as they approach the slip surface (Fig. 9c). Large remnant grains (up to $200 \mu \mathrm{m}$ ) in the bulk gouge are often rimmed by fractured tails of finer-grained aggregates (grain size $<10 \mu \mathrm{m}$ ), and resemble mantled porphyroclasts in mylonites (e.g. Snoke et al., 1998; Trouw and Passchier, 2009) 

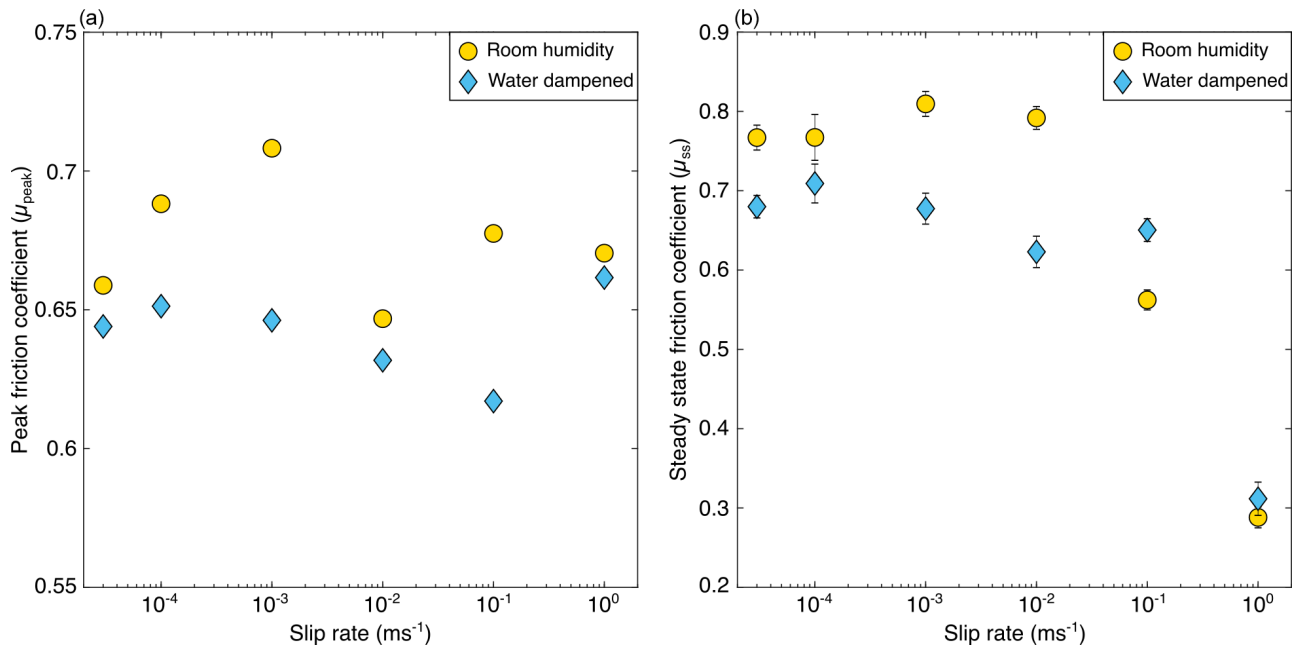

Figure 3. Peak and steady-state friction coefficients. (a) For experiments that showed slip strengthening, the peak friction coefficient was calculated just before the onset of strengthening behaviour in the first $0.1 \mathrm{~m}$ of slip. For experiments showing dynamic weakening, the peak friction immediately precedes the friction drop (see Fig. $2 b$ and d). (b) Steady-state friction coefficient was calculated at displacements between 0.15 and $0.35 \mathrm{~m}$.
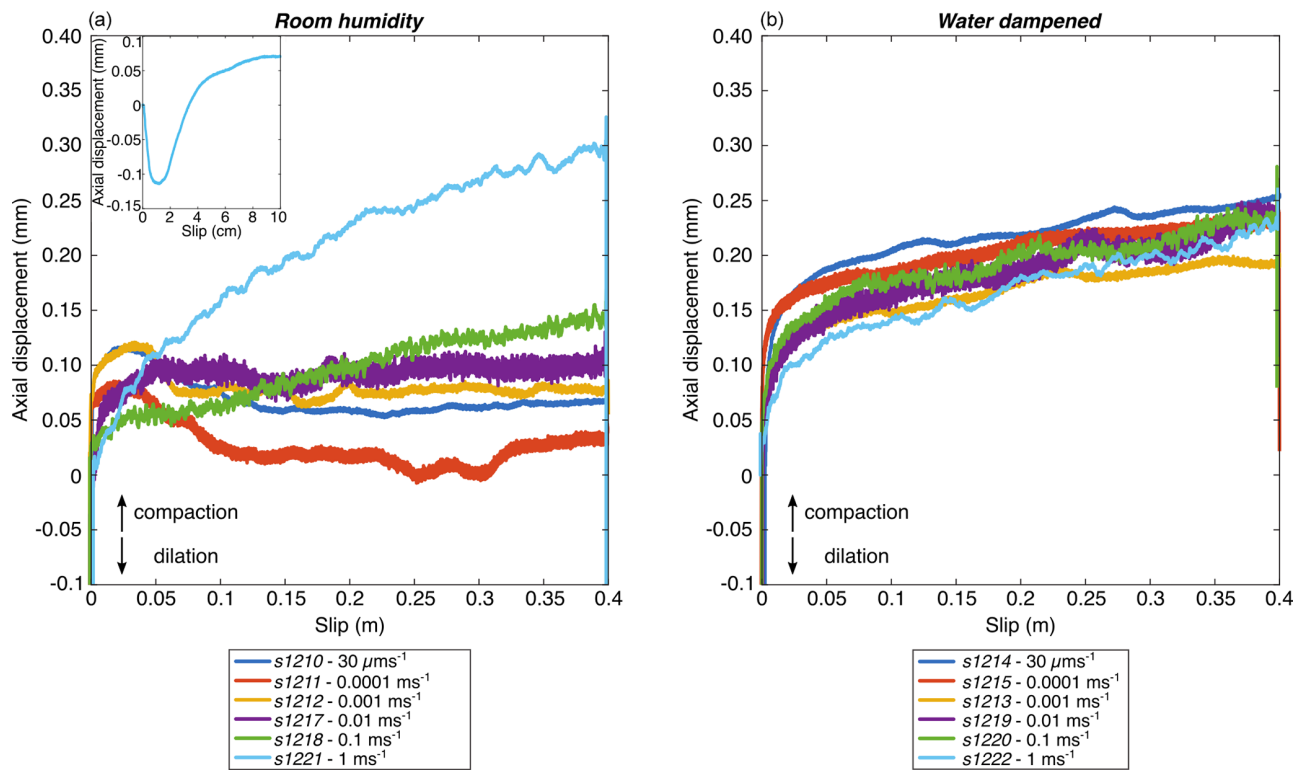

Figure 4. Gouge thickness evolution with slip and slip rate. (a) Under room-humidity conditions and for slip rates of $V \leq 0.01 \mathrm{~m} \mathrm{~s}{ }^{-1}$, an initial compaction phase was followed by dilation (lasting $0.1-0.15 \mathrm{~m})$ and then constant thickness. At higher slip rates $\left(V \geq 0.1 \mathrm{~ms} \mathrm{~s}^{-1}\right.$ ), after a short initial dilatancy phase, the gouge compacted constantly throughout the whole experiment, with compaction rate increasing with slip rate. (b) Under water-dampened conditions, the gouge compacted at a similar rate at all investigated slip rates.

(arrow in Fig. 9a). At distances of $<400 \mu \mathrm{m}$ from the principal slip surface, the mean grain size decreases substantially, there are very few large surviving grains (up to ca. $100 \mu \mathrm{m}$ in size), and there is a greater degree of mixing between calcite and dolomite (see more uniform colouring in the upper part of EDS map in Fig. 10b). The principal slip zone consists of a 15-20 $\mu \mathrm{m}$ thick, extremely fine-grained layer $(\ll 1 \mu \mathrm{m}$ in size) composed of calcite, $\mathrm{Mg}$ calcite, dolomite, and periclase (EDS and XRPD analysis; Figs. 6 and $9 \mathrm{c}-\mathrm{d})$. Calcite forms elongate aggregates with negligible porosity that display an aggregate-preferred orientation with the long axes sub-parallel to the foliation (Fig. 9c-e). Dolomite-rich domains show higher porosity and preserve distinct grain structures (Fig. 9c-d). EBSD analysis of elongate calcite aggregates adjacent to the principal slip zone (Fig. 9e) shows a distinct crystallographic-preferred orientation with $c$ axes inclined sub-perpendicular to gouge layer boundaries (Fig. 9f; see also Demurtas et al., 2019b). Lo- 

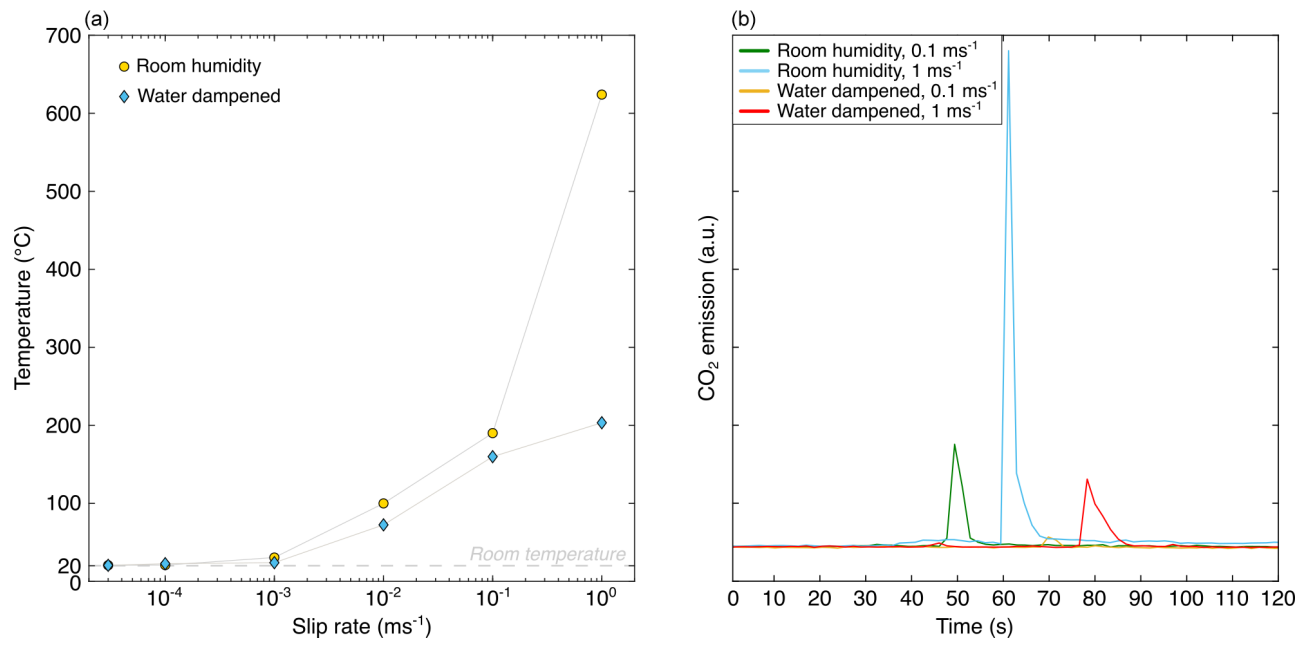

Figure 5. Peak temperatures and $\mathrm{CO}_{2}$ emissions. (a) Maximum temperature measured by the thermocouple located closest to the gouge layer (see Fig. $1 \mathrm{~b}$ for location). (b) $\mathrm{CO}_{2}$ emissions for experiments at $V \geq 0.1 \mathrm{~m} \mathrm{~s}^{-1}$ in both room-humidity and water-dampened conditions. Greater emissions occur at room-humidity conditions, but smaller and distinct peaks are also observed in the presence of water.

cally, a ca. 30-40 $\mu$ m thick layer adjacent to the principal slip zone includes dolomite grains with diffuse internal cracking, clusters of small holes, and vesicular rims previously interpreted as resulting from degassing during decarbonation of comminuted dolomite grains (Fig. 9c; Mitchell et al., 2015; Demurtas et al., 2019b).

\subsubsection{Microstructures of water-dampened experiments}

In the bulk gouges, the region furthest from the slip zone is composed of grains that show very limited fracturing and resemble the starting materials (Fig. 10a, d; compare with Fig. 1e). Towards the slip zone, grains are increasingly fractured and become rounder. As in the room-humidity experiments, most of the larger "surviving" grains are composed of dolomite (Fig. 10e), consistent with data showing that calcite undergoes more efficient grain size reduction compared to dolomite (Smith et al., 2017; Demurtas et al., 2019a). Domain boundaries (e.g. between intact bulk gouge and comminuted gouge) are often gradational (Fig. 10d), and the total thickness of the comminuted zone is observed to decrease at higher slip rates (from ca. $1500 \mu \mathrm{m}$ thick at $30 \mu \mathrm{m} \mathrm{s}^{-1}$ to ca. $150 \mu \mathrm{m}$ thick at $1 \mathrm{~m} \mathrm{~s}^{-1}$ ). The principal slip zone consists of an ultrafine-grained matrix (grain size $<1 \mu \mathrm{m}$ ) composed of a mixture of calcite and dolomite, with a few well-rounded surviving dolomite grains up to $20-30 \mu \mathrm{m}$ in size (Fig. 10bc). At the lowest slip rate (i.e. $30 \mu \mathrm{m} \mathrm{s}^{-1}$ ), the principal slip zone has a sharp but wavy boundary (characteristic wavelength of ca. $300 \mu \mathrm{m}$ ) with the underlying gouge (Fig. 10d) and contains irregular flame-like structures defined by subtle variations in the content of calcite and dolomite (Fig. 10b). The principal slip zone is cut by discrete slip surfaces oriented sub-parallel to the boundaries of the gouge (Y shear, Fig. 10c). Experiments performed at $30 \mu \mathrm{m} \mathrm{s}^{-1}$ with increas- ing displacements (s1327, s1329, s1328, s1330-s1214 with displacements of 0.05-0.1-0.2-0.4 m, respectively; Table 1) show that the three distinct microstructural domains are already recognisable after $<0.05 \mathrm{~m}$ of slip (Fig. 10d) and that the final thickness of each microstructural domain is a function of total slip and slip rate. At a slip rate of $0.1 \mathrm{~m} \mathrm{~s}^{-1}$, the comminuted principal slip zone shows distinct grain size grading, characterised by an abundance of relatively large and angular dolomite particles towards the stationary side of the slip zone and an absence of such particles towards the rotary side (Fig. 10e). Measurements of the thickness of the principal slip zone at different slip rates (Fig. 8) show a loglinear decrease in thickness from ca. $400 \mu \mathrm{m}$ at $30 \mu \mathrm{m} \mathrm{s}^{-1}$ to ca. $30 \mu \mathrm{m}$ at $1 \mathrm{~m} \mathrm{~s}^{-1}$.

At a slip rate of $1 \mathrm{~m} \mathrm{~s}^{-1}$, the gouge contains an intensely comminuted ca. 300-400 $\mu \mathrm{m}$ thick layer bordering the principal slip zone (Fig. 10f). The transition between the two domains is sharp and characterised in places by the occurrence of discrete Y shears. The principal slip zone consists of lensshaped patches of a calcite-rich and fine-grained (grain size $<1 \mu \mathrm{m}$ ) layer ca. $30 \mu \mathrm{m}$ thick with negligible porosity, which is embedded in a highly comminuted and fine-grained matrix containing a few larger dolomite grains. The principal slip surface cuts sharply through this layer and truncates larger clasts (Fig. 10f-g). Locally, reworked angular fragments of the principal slip zone are found (Fig. 10h).

\section{Discussion}

\subsection{Microstructural evolution and weakening mechanisms in calcite-dolomite mixtures}

The mechanical behaviour and microstructural evolution of calcite-dolomite gouges show substantial differences based 


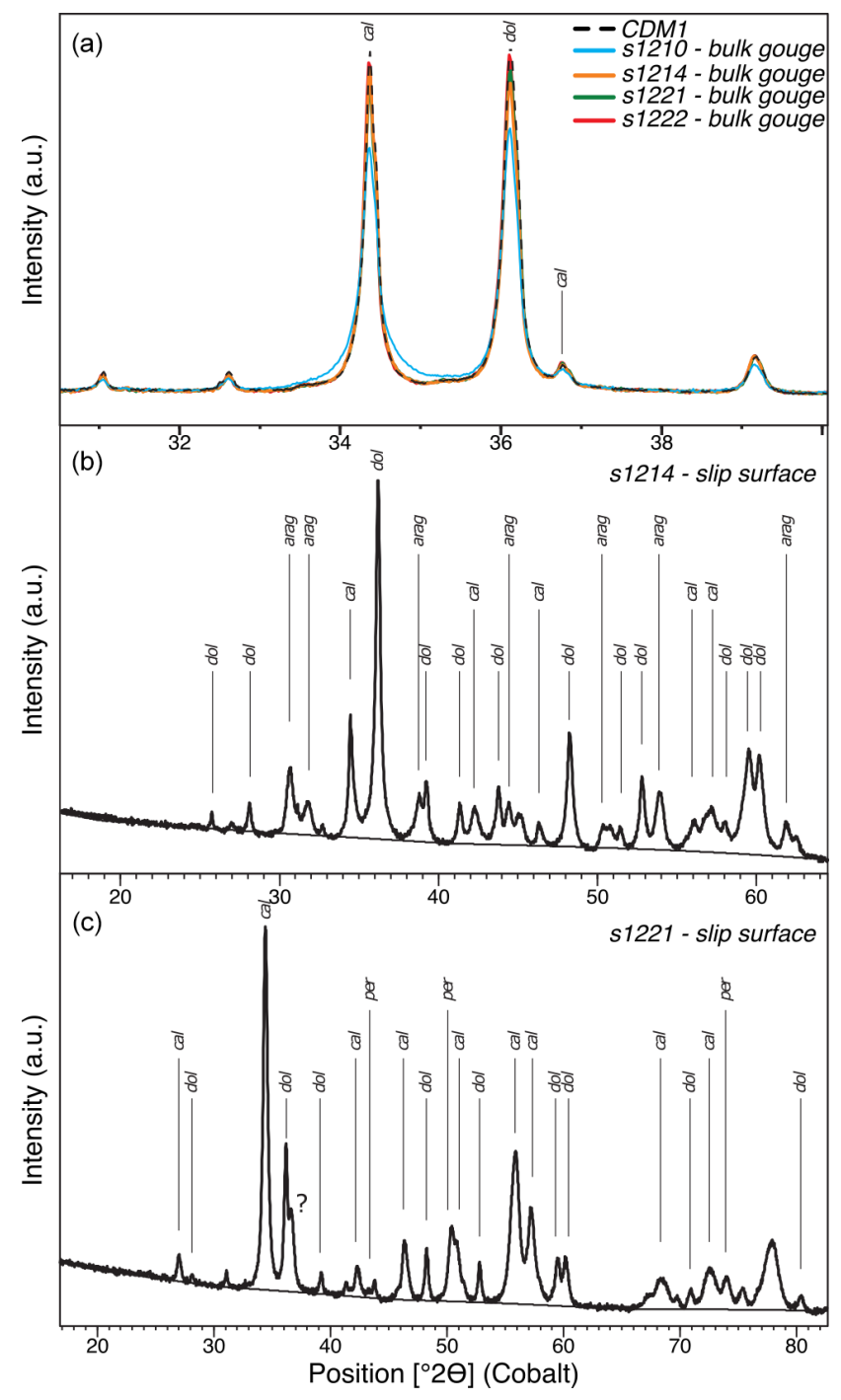

Figure 6. XRPD analysis of bulk gouge and slip surfaces. (a) Bulk gouge shows a Lorentzian profile for the main calcite peak in experiment s1210, suggesting either a large crystallite size distribution or microstrain as a result of intense comminution involving a large fraction of the gouge. (b) At $30 \mu \mathrm{m} \mathrm{s}^{-1}$ in water-dampened conditions, traces of aragonite are found on the slip surface as a result of calcite polymorphic transformation during prolonged mechanical grinding. (c) For s1221 ( $1 \mathrm{~m} \mathrm{~s}^{-1}$ in room-humidity conditions), presence of $\mathrm{Mg}$ calcite and periclase $(\mathrm{MgO})$ on the mirror-like slip surface is observed due to decarbonation of dolomite.

on the availability of water during deformation (Fig. 11). In room-humidity conditions, slip strengthening at slip rates $\leq 0.01 \mathrm{~m} \mathrm{~s}^{-1}$ is associated with (i) initial compaction followed by dilation (Fig. 4a) and (ii) the development of a $>500 \mu \mathrm{m}$ thick slip zone composed of a fine-grained (ca. $1 \mu \mathrm{m})$ calcite-dolomite mixture cut by $\mathrm{Y}-, \mathrm{R}$-, and $\mathrm{R}_{1}$-shear bands (Fig. 7). These observations have previously been interpreted to relate to the development and broadening of a distributed zone of deformation during strain hardening (e.g. Marone et al., 1990; Beeler et al., 1996; Rathbun and Marone, 2010). This is also supported by widening of the main peaks for calcite and dolomite in XRPD analysis (Fig. 6a), which is interpreted to result from a decrease in the mean crystallite size or deformation-induced microstrain within the crystallites (e.g. Ungár, 2004). A much shorter initial period of dilatancy is observed in experiments performed at $V \geq 0.1 \mathrm{~m} \mathrm{~s}^{-1}$ (Fig. 4a), and this correlates with (i) a transition from slip hardening to slip weakening (Figs. 2-3) and (ii) the development of a well-defined, localised principal slip zone that accommodates most of the strain after it forms (Figs. 7e-f, 9 and 11) (see also Han et al., 2007; Fondriest et al., 2013; Smith et al., 2013, 2015; Green et al., 2015; De Paola et al., 2015; Mitchell et al., 2015; Rempe et al., 2017; Pozzi et al., 2019; Demurtas et al., 2019b). The switch to slip weakening and a higher degree of strain localisation is also associated with a significant temperature rise generated within the principal slip zone (Fig. 5a), $\mathrm{CO}_{2}$ emissions (Fig. 5b), and the formation of $\mathrm{Mg}$ calcite and periclase in samples collected from the principal slip zone (Fig. 6c). Collectively, these observations suggest that the temperature rise at relatively high slip velocities triggered dynamic weakening and decarbonation of dolomite (and possibly calcite).

At high slip rates $\left(V \geq 0.1 \mathrm{~m} \mathrm{~s}^{-1}\right)$, the onset of dynamic weakening in carbonate gouges deformed at room humidity has been interpreted as a consequence of local heating along incipient slip surfaces, which eventually coalesce into a localised and through-going shear band (De Paola et al., 2015; Smith et al., 2015; Rempe et al., 2017). Further slip then increases the bulk temperature due to continued frictional heating in the principal slip zone and dissipation of heat in to the bulk gouge, resulting in local gouge recrystallisation (Smith et al., 2015). Under these conditions, high strain rates can be accommodated by temperature- and grain-size-dependent deformation mechanisms leading to "viscous" flow (Green et al., 2015; De Paola et al., 2015; Pozzi et al., 2018, 2019; Demurtas et al., 2019b). Demurtas et al. (2019b) performed transmission Kikuchi diffraction (TKD) analysis on electrontransparent samples of the low porosity, fine-grained principal slip zone of experiment s1221 ( $V=1 \mathrm{~m} \mathrm{~s}^{-1}$ under roomhumidity conditions; Fig. 9c) to investigate the deformation mechanisms active during coseismic sliding in calcitedolomite mixtures. Their results show that the principal slip zone is composed of a nanogranular aggregate made of two grain populations: (i) nanograins $100-300 \mathrm{~nm}$ in size exhibiting low internal lattice distortion, compatible with deformation by grain-size-sensitive creep, and (ii) nanograins $>800 \mathrm{~nm}$ in size showing development of subgrains, suggesting deformation by grain-size-insensitive creep (Demurtas et al., 2019b). Although the maximum temperature measured during deformation in the present experiments was $621^{\circ} \mathrm{C}$ (Fig. 5a), accommodation of the calculated strain rates $\left(\dot{\gamma}=6 \times 10^{3} \mathrm{~s}^{-1}\right)$ could be explained by a significant decrease of the activation energy for creep mechanisms (and also decarbonation reactions) due to the nanogranular na- 

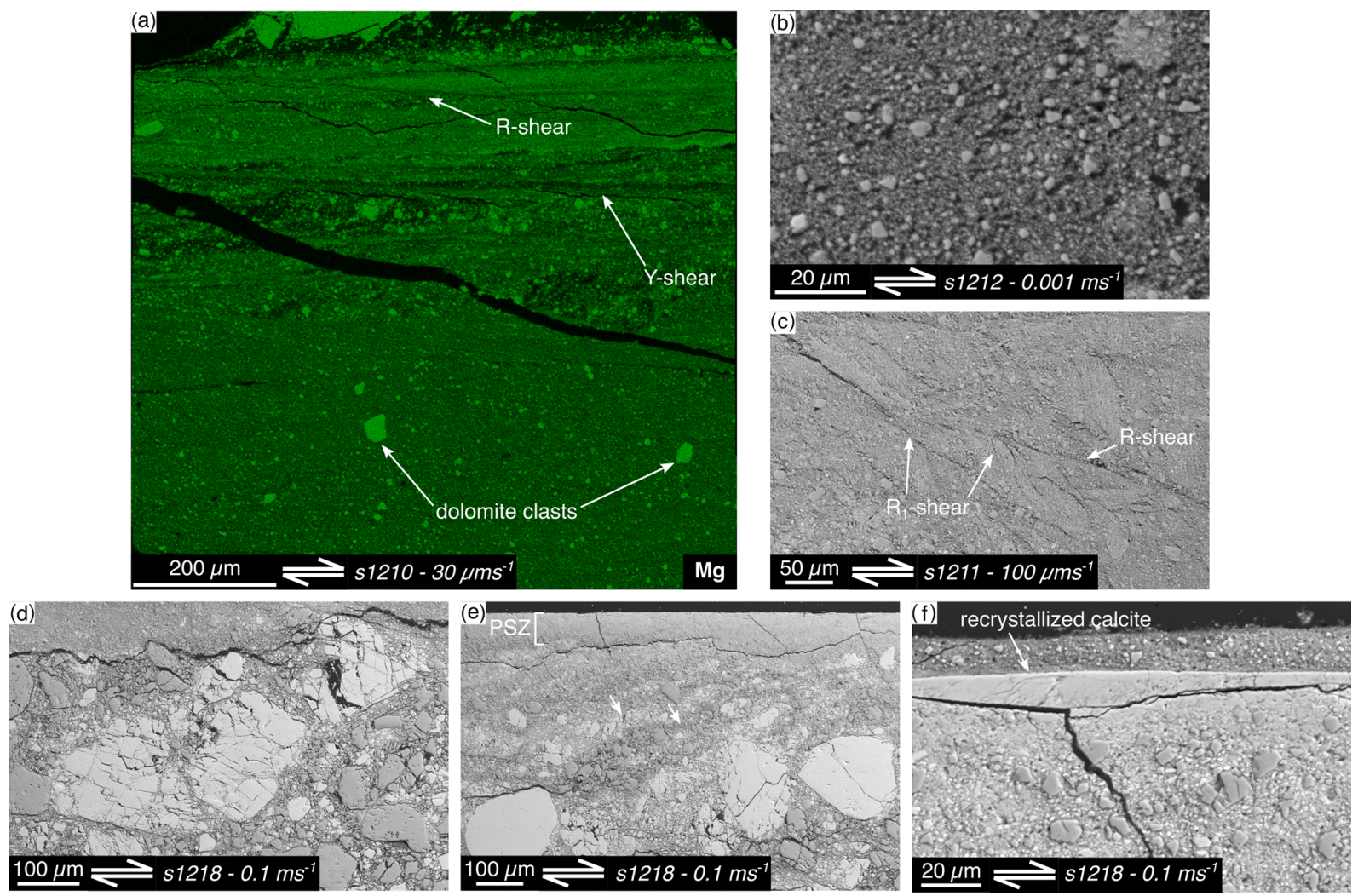

Figure 7. Microstructures of experiments in room-humidity conditions and $V \leq 0.1 \mathrm{~m} \mathrm{~s}^{-1}$. (a) $\mathrm{Mg}$ element map of the thick slip zone highlighting the location of remnant dolomite clasts. (b) Detail of the fine-grained matrix in the slip zone made of a calcite-dolomite mixture with surviving sub-rounded dolomite clasts up to few tens of micrometres in size. (c) The fine-grained slip zone is commonly cut by Y-, $\mathrm{R}$ - and $\mathrm{R}_{1}$-shear bands crosscutting each other. (d) Enhanced grain size reduction in calcite grains due to fracturing along cleavage planes. (e) Development of a weak foliation adjacent to the principal slip zone at $V=0.1 \mathrm{~m} \mathrm{~s}^{-1}$. (f) Patches of dynamically recrystallised calcite along the principal slip zone at $V=0.1 \mathrm{~m} \mathrm{~s}^{-1}$.

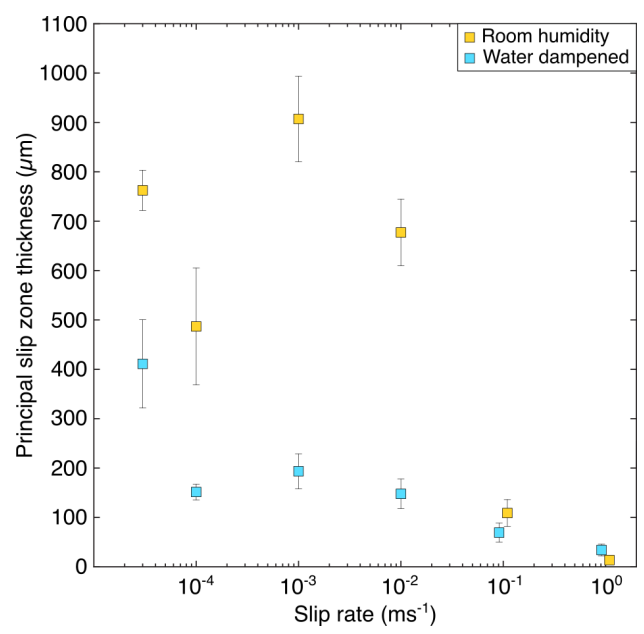

Figure 8. Slip zone thickness evolution with slip rate and presence of water. The thickness of the localised slip zone decreases almost linearly with $\log (V)$ in water-dampened experiments. For roomhumidity conditions, partial sample loss after the experiment means slip zone thickness values are a minimum estimate. ture of the particles (Demurtas et al., 2019b). Similar observations were documented by Pozzi et al. (2019) in experimental nanogranular principal slip zones in pure calcite gouges deformed at coseismic slip rates. Alternatively, the temperatures achieved in the slip zones of high-velocity $\left(V=1 \mathrm{~m} \mathrm{~s}^{-1}\right)$ but short-duration experiments $(<0.5 \mathrm{~s})$ could be higher than those measured with thermocouples and estimated using numerical models. The thermocouples used here were located a few millimetres from the edge of the slipping zone (Fig. 1b). Additionally, they have large thermal inertia and low real acquisition rates because the electric potential developing in response to temperature changes is very slow (0.1-0.5 s) compared to the duration of the experiments (ca. $0.5 \mathrm{~s}$ ) (Sarnes and Schrüfer, 2007). Recent studies in which the temperature during experimental seismic slip was measured with optical fibres located inside the slip zone (in situ measurements at acquisition rates of $1 \mathrm{kHz}$ ) detected temperatures $300-400^{\circ} \mathrm{C}$ higher than those measured with thermocouples (Aretusini et al., 2019). Temperatures in the slipping zone substantially higher than $621{ }^{\circ} \mathrm{C}$ would render grainsize- and temperature-dependent deformation mechanisms 

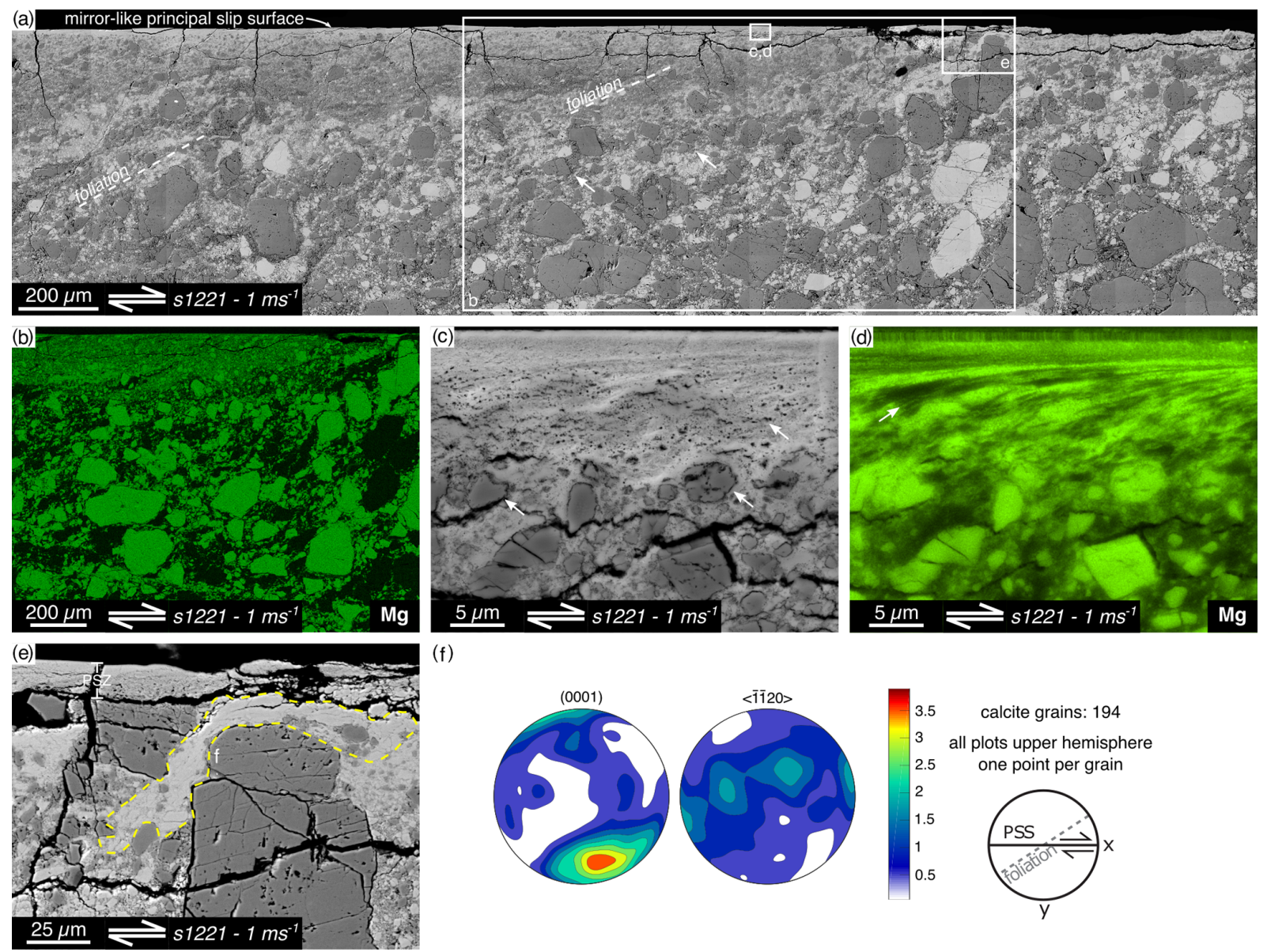

calcite grains: 194

all plots upper hemisphere

one point per grain

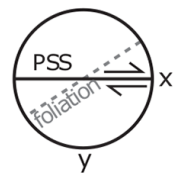

Figure 9. Microstructures of experiments in room-humidity conditions and $V=1 \mathrm{~m} \mathrm{~s}^{-1}$. (a) Development of a foliation consisting of alternation of calcite- and dolomite-rich domains that are antithetically inclined ca. $40^{\circ}$ from the principal slip surface (PSS) and become sub-parallel to the gouge boundaries when approaching the PSS. Larger dolomite (and when present calcite) clasts have tails of fine-grained material, resembling mantled porphyroclasts. (b) Mg element map highlighting foliation development in the bulk gouge. (c) Dolomite clasts adjacent to the principal slip zone are characterised by internal holes and vesicular rims interpreted being as due to degassing during dolomite decarbonation reaction. Banding of low and higher porosity in the principal slip zone is an indicator for dolomite content. (d) Mg element map of (c), showing dolomite and calcite banding in the principal slip zone. (e) Transition from the principal slip zone to the underlying fractured and foliated gouge, with calcite showing evidence of dynamic recrystallisation. (f) Orientation data for calcite in the area highlighted in (e) showing the development of a clear CPO along the $c$ axes.

more efficient. Instead, in the case of experiment s1218 performed at $V=0.1 \mathrm{~m} \mathrm{~s}^{-1}$, the moderate dynamic weakening $\left(\mu_{\mathrm{ss}}=0.55\right)$ can be related to more limited frictional heating within the principal slip zone both in time (max temperature measured of $190^{\circ} \mathrm{C}$, Fig. 5a) and space (patchy recrystallised areas in Fig. 7e-f). However, the temperature increase was at least locally sufficiently large to decompose dolomite (i.e. ca. $550{ }^{\circ} \mathrm{C}$ ), as testified by the clear $\mathrm{CO}_{2}$ peak measured during shearing at this velocity (Fig. 5 b).

In water-dampened conditions, the mechanical behaviour of the calcite-dolomite mixtures is similar (slight slip strengthening to slip neutral) at all slip rates up to $0.1 \mathrm{~m} \mathrm{~s}^{-1}$ (Fig. 2c). The thickness of the principal slip zone decreases log-linearly with increasing slip rate, indicating a progressively higher degree of localisation (Figs. 8 and 11). How- ever, this has no obvious effect on the steady-state friction coefficient (Fig. 3b), possibly suggesting that the steady state is controlled by strain and that strain is kept constant by microstructural reorganisation distributed within the slip zone. The principal slip zone is composed of a very fine-grained $(\ll 1 \mu \mathrm{m})$ matrix of calcite and dolomite that includes a few well-rounded dolomite clasts up to $20-30 \mu \mathrm{m}$ in size (Fig. 10). The similarity in microstructure at all investigated slip rates suggests that water has a major role in promoting faster grain size reduction at the onset of slip, possibly by decreasing the surface energy and yield stress of calcite and dolomite (Risnes et al., 2005; Røyne et al., 2011). XRPD analysis of the slip surface of experiment s1214 $\left(30 \mu \mathrm{m} \mathrm{s}^{-1}\right)$ showed the formation of aragonite (Fig. 6b). Given that the starting materials were composed of calcite and dolomite 

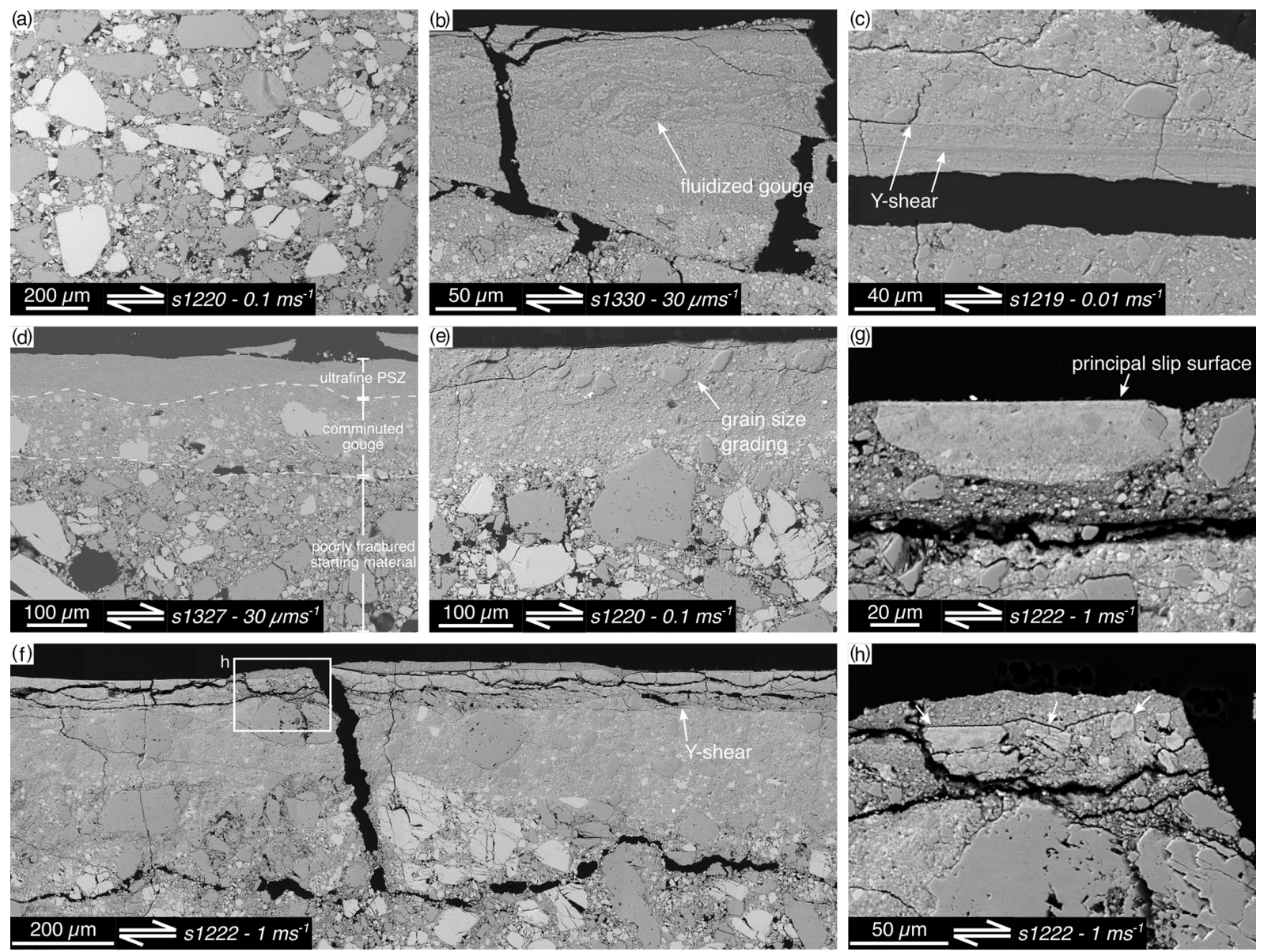

Figure 10. Microstructures of experiments in water-dampened conditions. (a) The bulk gouge is made of a poorly fractured calcite and dolomite mixture highly resembling the starting material. (b) Occurrence of fluidised structures in the principal slip zone of experiments performed at $30 \mu \mathrm{m} \mathrm{s}^{-1}$. (c) At $0.0001 \mathrm{~m} \mathrm{~s}^{-1} \leq V<0.1 \mathrm{~m} \mathrm{~s}^{-1}$, the principal slip zone is cut by multiple Y shears. (d) In the presence of fluid water, an ultrafine principal slip surface develops, overlying a highly comminuted gouge which then transitions to a poorly fractured starting material. (e) At $V=0.1 \mathrm{~m} \mathrm{~s}^{-1}$, grain size grading is observed in the principal slip zone, with larger clasts occurring near the principal slip surface. (f) At $V=1 \mathrm{~m} \mathrm{~s}^{-1}$, strain localises on a compacted, low-porosity, recrystallised slip zone, which (g) is not continuous and (h) often found broken and reworked.

only, the aragonite must have formed during deformation. Li et al. (2014) documented polymorphic transformation of calcite into aragonite due to mechanical grinding in a dry (i.e. room humidity) environment. Our observations therefore suggest that relatively dry patches could develop in the gouge layer during slip (or were present at the onset of slip) or that such transformation is also possible under waterdampened conditions.

In water-dampened experiments at $1 \mathrm{~m} \mathrm{~s}^{-1}$, abrupt dynamic weakening preceded by a very short-lived strengthening phase has previously been documented in experiments on calcite gouges (Rempe et al., 2017, 2020) and calcite marbles (Violay et al., 2014). In gouges, Rempe et al. $(2017,2020)$ suggested that the rapid onset of dynamic weakening could be related to faster grain size reduction in the presence of water, leading to an early switch from brittle deformation to grain-size-sensitive creep in the principal slip zone, analo- gous to the process suggested to occur in dry gouges (De Paola et al., 2015; Demurtas et al., 2019b; Pozzi et al., 2019). However, there is an apparent discrepancy between the relatively low maximum temperature measured close to the principal slip zone in water-dampened experiments $\left(200^{\circ} \mathrm{C}\right.$ at $V=1 \mathrm{~m} \mathrm{~s}^{-1}$; Fig. 5a), and the observed $\mathrm{CO}_{2}$ production (Fig. 5b) combined with microstructural evidence for recrystallisation during deformation (Fig. 10f-g). As previously discussed, this could be due to an underestimate of the peak temperature (Aretusini et al., 2019). Alternatively, vaporisation of water during coseismic sliding could buffer the temperature due to the endothermic nature of the phase transition (Chen et al., 2017a, b). If the pore pressure increase is sufficiently large, then fluids (and vapour) could pressurise the gouge layers and play an important role during dynamic weakening. Finally, Ohl et al. (2020) proposed that mechanical liming (see Martinelli and Plescia, 2004) along natural 


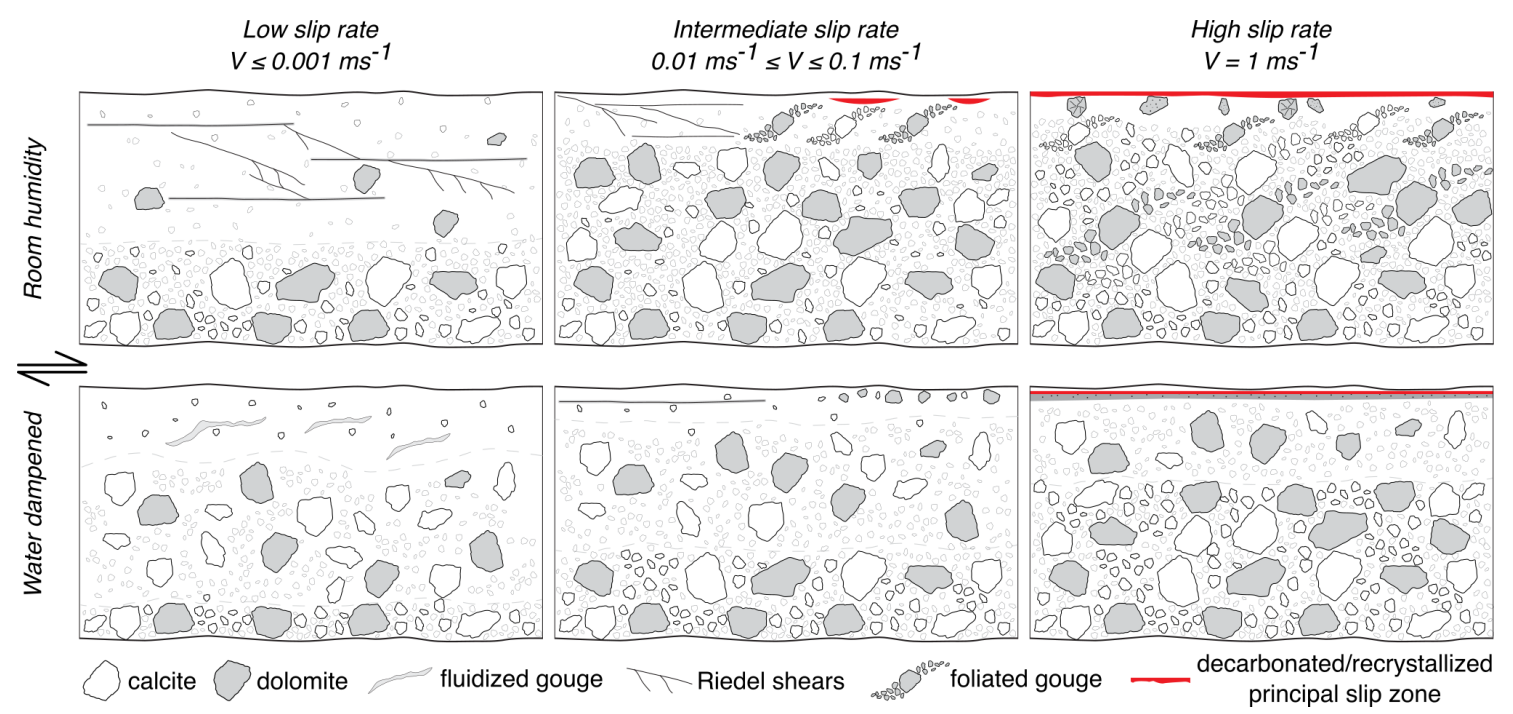

Figure 11. Summary of microstructural evolution at different slip rates and deformation conditions.

faults could be a possible slip weakening mechanism that does not necessarily involve a macroscopic temperature increase of $>500-600^{\circ} \mathrm{C}$.

\subsection{Implications for natural fault zones}

\subsubsection{Gouge fluidisation at slip rates between $30 \mu \mathrm{m} \mathrm{s}$ and $0.1 \mathrm{~m} \mathrm{~s}^{-1}$}

The slip zone of the water-dampened experiment performed at $30 \mu \mathrm{m} \mathrm{s}^{-1}$ is characterised by flame-like structures and domain boundaries that display a characteristic wavelength (Fig. 10b, d). Similar structures are typical of soft sediment deformation (Allen, 1985) and have also been described within fault cores (Brodsky et al., 2009), where they are interpreted to result from grain mobilisation promoted by fluid overpressure and a difference in viscosity between two adjacent layers during deformation. Additionally, the occurrence of grain size grading within the water-dampened principal slip zone formed at $0.1 \mathrm{~m} \mathrm{~s}^{-1}$ is indicative of grain rearrangement due to frictional sliding (see Masoch et al., 2019, and reference therein), referred to as the "Brazil nut" effect, a phenomenon observed when large grains move to the top of a fluidised layer due to differences in dispersal pressure between large and small particles (Williams, 1976). Grain size grading was reported by Boullier et al. (2009) from the principal slip zone of the $1999 M_{\mathrm{W}}$ 7.6 Chi-Chi earthquake in Taiwan and from exhumed normal faults in alpine Corsica (Masoch et al., 2019). Additionally, similar microstructures were produced by Boulton et al. (2017) in high-velocity rotary-shear experiments $\left(V=1 \mathrm{~m} \mathrm{~s}^{-1}\right)$ performed on clay-rich drill chips retrieved from the Alpine Fault (New Zealand). As in the experiments by Boulton et al. (2017), grain size grading in our experiments was observed only in water-dampened conditions. Collectively, the pres- ence of flame-like structures, undulating domain boundaries with a characteristic wavelength, and grain size grading, suggests that water-dampened gouges experienced fluidisation at slip rates between $30 \mu \mathrm{m} \mathrm{s}^{-1}$ and $0.1 \mathrm{~m} \mathrm{~s}^{-1}$. This is significant because textures and microstructures related to fluidisation in natural gouges and cataclasites are often interpreted to form during coseismic slip at high velocities (e.g. Monzawa and Otsuki, 2003; Rowe et al., 2005; Boullier et al., 2009; Brodsky et al., 2009; Demurtas et al., 2016; Boulton et al., 2017; Smeraglia et al., 2017). However, our observations suggest that fluidisation might occur at lower slip velocities if local fluid pressures can build up in deforming gouge layers and may not necessarily be an indicator of coseismic slip.

Various mechanisms have been proposed to account for fluidisation of granular materials in fault zones, including (i) frictional heating and thermal pressurisation (Boullier et al., 2009), (ii) dilation that limits grain-grain contacts (Borradaile, 1981; Monzawa and Otsuki, 2003), and (iii) focussed fluid flow along slip zones during and after coseismic sliding (e.g. fault-valve mechanism of Sibson, 1990). In our experiments, temperature measurements made during slip at $30 \mu \mathrm{m} \mathrm{s}^{-1}$ suggest that significant frictional heating is unlikely, and therefore thermal pressurisation is an unlikely mechanism within the slip zone. Water-dampened experiments are characterised by continuous compaction, which also excludes the dilation-related hypothesis of Borradaile (1981). The rapid grain size reduction occurring at the onset of slip, particularly for calcite, creates a principal slip zone that could readily accommodate continuous compaction. Within the principal slip zone, local variations in grain size could create transient differences in gouge permeability that may promote pore fluid pressure build-up. A sudden release of fluid from pressurised patches could result in gouge mobilisation and injection of material into the adjacent 
regions. Such variations in permeability and pore pressure are likely to occur on a local level that may not the recorder by bulk variations of gouge thickness during deformation.

\subsubsection{Foliation development in calcite-dolomite gouges at coseismic slip rates}

Foliated gouges and cataclasites are common fault rocks in the brittle upper crust (Snoke et al., 1998). Typically, they are interpreted to form due to a combination of cataclasis and dissolution-precipitation reactions during aseismic fault creep (e.g. Rutter et al., 1986; Chester and Chester, 1998; Lin, 2001; Collettini and Holdsworth, 2004; Jefferies et al., 2006; De Paola et al., 2008; Wallis et al., 2013). Experimental observations support this idea and show that well-defined foliations can form as a result of dissolution-precipitation reactions accompanied by granular flow and frictional sliding at low slip rates $\left(V<1 \mu \mathrm{m} \mathrm{s}^{-1}\right.$; Bos et al., 2000; Niemeijer and Spiers, 2006).

However, the association of foliated fault rocks with possible microstructural indicators of seismic slip in natural fault rocks (e.g. slip zones containing recrystallized material, see Demurtas et al., 2016) led Smith et al. (2017) to investigate the possibility that some foliated gouges and cataclasites might have a coseismic origin. Rotary-shear experiments performed at a slip rate of $1.13 \mathrm{~m} \mathrm{~s}^{-1}$ on gouges composed of $50 \mathrm{wt} \%$ calcite and $50 \mathrm{wt} \%$ dolomite showed the development of a foliation defined by an organised banding of heavily fractured calcite and dolomite clasts (Smith et al., 2017). Experiments performed at increasing displacements revealed that the foliations are established during the initial strengthening phase, when distributed strain throughout the bulk gouge causes grain comminution and distributed shearing. Once dynamic weakening occurs, strain progressively localises into a single continuous principal slip zone, and the foliation in the bulk gouge does not show any further microstructural change. Shear strain analysis of the foliated layers showed that relatively low values of $\operatorname{strain}(\gamma<4)$ are needed to develop a foliation. Based on their observations, Smith et al. (2017) suggested that some natural foliated gouges and cataclasites characterised by compositional banding, grain size variations, and preferred particle or fracture alignments could form via distributed brittle flow as strain localises during coseismic shearing, especially if such foliations are found in proximity to microstructural indicators of coseismic slip. The experiments presented in this paper allow us to test this hypothesis over a wider range of slip rates (i.e. $30 \mu \mathrm{m} \mathrm{s}^{-1}-1 \mathrm{~m} \mathrm{~s}^{-1}$ ) and deformation conditions (i.e. room humidity versus water dampened). In these new experiments, the formation of well-defined foliations throughout the bulk gouge was only observed at high slip rates $\left(V=1 \mathrm{~m} \mathrm{~s}^{-1}\right)$ and room humidity conditions (Figs. 9, 11 ), corresponding to the conditions presented in Smith et al. (2017). Local foliation development was also observed in lower velocity experiments at room humidity, although this was restricted to regions $<400 \mu \mathrm{m}$ from the principal slip surface (Fig. 7e).

Our new experiments support the hypothesis presented in Smith et al. (2017) that well-defined foliations in calcitedolomite gouges can form during high velocity sliding in carbonate gouges, and could be used in conjunction with other microstructures (e.g. seismic slip indicators) to better understand localisation processes in faults. The lowest slip velocity studied here (i.e. $30 \mu \mathrm{m} \mathrm{s}^{-1}$ ) is still too high for pressure solution to be efficient in calcite or dolomite at room temperature. Lower slip rates might promote the activation of pressure solution, which could result in the formation of a foliation under certain conditions. Grain elongation and foliation development have previously been reported in experiments performed on calcite-dolomite mixtures by Delle Piane et al. (2009) and on calcite by Verberne et al. (2017). However, in the former case, the deformation conditions (i.e. torsion experiments at temperatures of $700-800^{\circ} \mathrm{C}$, confining pressure of $300 \mathrm{MPa}$, and shear strain rate of $3 \times 10^{-4}-10^{-5} \mathrm{~s}^{-1}$ ) were representative of middle to lower crustal depths, rather than the low-pressure, low-temperature ambient conditions explored here. Although the slip rates in Verberne et al. (2017) were closer to the ones explored in this study (i.e. $1 \mathrm{~nm} \mathrm{~s}^{-1}$ to $\left.100 \mu \mathrm{m} \mathrm{s}^{-1}\right)$, the temperature $\left(T=550^{\circ} \mathrm{C}\right)$ and stress conditions (effective normal stress of $50 \mathrm{MPa}$ and pore fluid pressure of $100 \mathrm{MPa}$ ) were designed to investigate the brittle-ductile transition at the base of the seismogenic zone rather than shallow faulting.

\section{Conclusions}

A series of rotary-shear experiments was performed on gouges composed of $50 \mathrm{wt} \%$ calcite and $50 \mathrm{wt} \%$ dolomite to develop an understanding of microstructural evolution at a range of slip rates $\left(30 \mu \mathrm{m} \mathrm{s}^{-1}-1 \mathrm{~m} \mathrm{~s}^{-1}\right)$, fluid conditions (room humidity and water dampened), total displacements (0.05-0.4 m), and normal load of 17.5 MPa.

The evolution of the apparent friction coefficient is strongly influenced by the presence of water. Under roomhumidity conditions, slip strengthening is observed up to slip rates of $0.01 \mathrm{~m} \mathrm{~s}^{-1}$, above which dynamic weakening occurs. In water-dampened conditions, slight slip strengthening to slip neutral friction characterises experiments up to slip velocities of $0.1 \mathrm{~m} \mathrm{~s}^{-1}$, above which dynamic weakening occurs abruptly. The mechanical differences observed under room-humidity and water-dampened conditions are also reflected in the microstructures of the deformed gouge layers. At room humidity, slip strengthening is associated with diffuse deformation and the development of a relatively thick slip zone cut by Y-, R-, and $\mathrm{R}_{1}$-shear bands. The onset of dynamic weakening is concomitant with the development of a localised principal slip zone containing evidence of dolomite decarbonation and calcite recrystallisation. In the presence of water, evidence of gouge fluidisation within a fine-grained 
principal slip zone is observed at slip rates from $30 \mu \mathrm{m} \mathrm{s}^{-1}$ to $0.1 \mathrm{~m} \mathrm{~s}^{-1}$, suggesting that fluidisation may not be restricted to coseismic slip rates. At $1 \mathrm{~m} \mathrm{~s}^{-1}$, the principal slip zone is characterised by patches of recrystallised calcite that are locally broken and reworked.

The development of a well-defined foliation in the bulk gouge layer only occurs in room-humidity experiments at a slip rate of $1 \mathrm{~m} \mathrm{~s}^{-1}$, consistent with the work of Smith et al. (2017). This observation supports the notion that some foliated gouges and cataclasites may form during coseismic slip in natural carbonate-bearing faults.

Data availability. Mechanical data from the experiments are available upon request from the corresponding author.

Supplement. The supplement related to this article is available online at: https://doi.org/10.5194/se-12-595-2021-supplement.

Author contributions. MD, SAFS, ES, and GDT designed the project. MD and ES performed the experiments. MD and SAFS performed the microstructural analysis. MD, SAFS, ES, and GDT were part of the discussion and contributed to the writing of the manuscript.

Competing interests. The authors declare that they have no conflict of interest.

Acknowledgements. Stefano Aretusini and Michele Fondriest are thanked for fruitful discussions. Marianne Negrini provided assistance with the SEM at the Otago Centre for Electron Microscopy, University of Otago. Federico Zorzi is thanked for performing the XRPD analysis, and Leonardo Tauro is thanked for assistance during thin-section preparation.

Financial support. Matteo Demurtas, Elena Spagnuolo, and Giulio Di Toro were supported by the European Research Council Consolidator, Seventh Framework Programme, grant project 614705 NOFEAR. Steven A. F. Smith acknowledges the Marsden Fund Council (projects UOO1417 and UOO1829) administered by the Royal Society of New Zealand.

Review statement. This paper was edited by Florian Fusseis and reviewed by Bart A. Verberne and John Bedford.

\section{References}

Allen, J. R. L.: Principles of Physical Sedimentology, George Allen and Unwin, Boston, 272 pp., 1985.

Aretusini S., Nuñez Cascajero, A., Spagnuolo, E., Tapetado, A., Vazquez, C., and Di Toro, G.: How hot is a lab-earthquake?, American Geophysical Union Fall Meeting, San Francisco, USA, 9-13 December 2019, 519812, M23E-0160, 2019.

Austin, N. J. and Kennedy, L. A.: Textural controls on the brittle deformation of dolomite: Variations in peak strength, in: Deformation Mechanisms, Rheology and Tectonics: from Minerals to the Lithosphere, vol. 243, edited by: Gapais, D., Brun, J. P., and Cobbold, P. R., Geological Society, London, Special Publications, 37-49, 2005.

Barber, D. J., Heard, H. C., and Wenk, H. R.: Deformation of dolomite single crystals from $20-800^{\circ} \mathrm{C}$, Phys. Chem. Miner., 7, 271-286, https://doi.org/10.1007/BF00311980, 1981.

Beeler, N. M., Tullis, T. E., Blanpied, M. L., and Weeks, J. D.: Frictional behavior of large displacement experimental faults, J. Geophys. Res.-Sol. Ea., 101, 8697-8715, https://doi.org/10.1029/96JB00411, 1996.

Bestmann, M., Kunze, K., and Matthews, A.: Evolution of a calcite marble shear zone complex on Thassos Island, Greece: Microstructural and textural fabrics and their kinematic significance, J. Struct. Geol., 22, 1789-1807, https://doi.org/10.1016/S0191-8141(00)00112-7, 2000.

Bestmann, M., Prior, D. J., and Grasemann, B.: Characterisation of deformation and flow mechanics around porphyroclasts in a calcite marble ultramylonite by means of EBSD analysis, Tectonophysics, 413, 185-200, https://doi.org/10.1016/j.tecto.2005.10.044, 2006.

Boneh, Y., Sagy, A., and Reches, Z.: Frictional strength and wear-rate of carbonate faults during high-velocity, steady-state sliding, Earth Planet. Sci. Lett., 381, 127-137, https://doi.org/10.1016/j.eps1.2013.08.050, 2013.

Borradaile, G. J.: Particulate flow of rock and the formation of cleavage, Tectonophysics, 72, 305-321, https://doi.org/10.1016/0040-1951(81)90243-2, 1981.

Bos, B., Peach, C. J., and Spiers, C. J.: Frictional-viscous flow of simulated fault gouge caused by the combined effects of phyllosilicates and pressure solution, Tectonophysics, 327, 173-194, 2000.

Boullier, A. M., Yeh, E. C., Boutareaud, S., Song, S. R., and Tsai, C. H.: Microscale anatomy of the 1999 ChiChi earthquake fault zone, Geochem. Geophy. Geosy., 10, 3, https://doi.org/10.1029/2008GC002252, 2009.

Boulton, C., Yao, L., Faulkner, D. R., Townend, J., Toy, V. G., Sutherland, R., Ma, S., and Shimamoto, T.: Highvelocity frictional properties of Alpine Fault rocks: Mechanical data, microstructural analysis, and implications for rupture propagation, J. Struct. Geol., 97, 71-92, https://doi.org/10.1016/j.jsg.2017.02.003, 2017.

Brodsky, E. E., Rowe, C. D., Meneghini, F., and Moore, J. C.: A geological fingerprint of low-viscosity fault fluids mobilized during an earthquake, J. Geophys. Res.-Solid Ea., 114, B01303, https://doi.org/10.1029/2008JB005633, 2009.

Busch, J. P. and van der Pluijm, B. A.: Calcite textures, microstructures and rheological properties of marble mylonites in the Bancroft shear zone, Ontario, Canada, J. Struct. Geol., 17, 677-688, https://doi.org/10.1016/0191-8141(94)00092-E, 1995. 
Chen, J., Niemeijer, A. R., and Fokker, P. A.: Vaporization of fault water during seismic slip, J. Geophys. Res.-Solid Ea., 122, 42374276, https://doi.org/10.1002/2016JB013824, 2017.

Chen, J., Niemeijer, A., Yao, L., and Ma, S.: Water vaporization promotes coseismic fluid pressurization and buffers temperature rise, Geophys. Res. Lett., 44, 5, https://doi.org/10.1002/2016GL071932, 2017.

Chester, F. M. and Chester, J. S.: Ultracataclasite structure and friction processes of the Punchbowl fault, San Andreas system, California, Tectonophysics, 295, 199-221, https://doi.org/10.1016/S0040-1951(98)00121-8, 1998.

Collettini, C. and Holdsworth, R. E.: Fault zone weakening and character of slip along low-angle normal faults: Insights from the Zuccale fault, Elba, Italy, J. Geol. Soc. London., 161, 10391051, https://doi.org/10.1144/0016-764903-179, 2004.

Davis, N. E., Kronenberg, A. K., and Newman, J.: Plasticity and diffusion creep of dolomite, Tectonophysics, 456, 127-146, https://doi.org/10.1016/j.tecto.2008.02.002, 2008.

De Bresser, J. H. P. and Spiers, C. J.: High-temperature deformation of calcite single crystals by $\mathrm{r}+$ and $\mathrm{f}+\mathrm{slip}$, in: Geological Society Special Publication, vol. 54, edited by: Knipe, R. J. and Rutter, E. H., Geological Society London, 285-298, 1990.

De Paola, N., Mirabella, F., Barchi, M. R., and Burchielli, F.: Early orogenic normal faults and their reactivation during thrust belt evolution: the Gubbio Fault case study, UmbriaMarche Apennines (Italy), J. Struct. Geol., 28, 1948-1957, https://doi.org/10.1016/j.jsg.2006.06.002, 2006.

De Paola, N., Collettini, C., Faulkner, D. R., and Trippetta, F.: Fault zone architecture and deformation processes within evaporitic rocks in the upper crust, Tectonics, 27, 1-21, https://doi.org/10.1029/2007TC002230, 2008.

De Paola, N., Chiodini, G., Hirose, T., Cardellini, C., Caliro, S., and Shimamoto, T.: The geochemical signature caused by earthquake propagation in carbonate-hosted faults, Earth Planet. Sci. Lett., 310, 225-232, https://doi.org/10.1016/j.eps1.2011.09.001, 2011a.

De Paola, N., Hirose, T., Mitchell, T., Di Toro, G., Viti, C., and Shimamoto, T.: Fault lubrication and earthquake propagation in thermally unstable rocks, Geology, 39, 35-38, https://doi.org/10.1130/G31398.1, 2011b.

De Paola, N., Holdsworth, R. E., Viti, C., Collettini, C., and Bullock, R.: Can grain size sensitive flow lubricate faults during the initial stages of earthquake propagation?, Earth Planet. Sci. Lett., 431, 48-58, https://doi.org/10.1016/j.epsl.2015.09.002, 2015.

Delle Piane, C., Burlini, L., and Grobety, B.: Reactioninduced strain localization: Torsion experiments on dolomite, Earth Planet. Sci. Lett., 256, 36-46, https://doi.org/10.1016/j.eps1.2007.01.012, 2007.

Delle Piane, C., Burlini, L., Kunze, K., Brack, P., and Burg, J. P.: Rheology of dolomite: Large strain torsion experiments and natural examples, J. Struct. Geol., 30, 767-776, https://doi.org/10.1016/j.jsg.2008.02.018, 2008.

Delle Piane, C., Burlini, L. and Kunze, K.: The influence of dolomite on the plastic flow of calcite. Rheological, microstructural and chemical evolution during large strain torsion experiments, Tectonophysics, 467, 145-166, https://doi.org/10.1016/j.tecto.2008.12.022, 2009.

Delle Piane, C., Clennell, M. B., Keller, J. V. A., Giwelli, A., and Luzin, V.: Carbonate hosted fault rocks: A review of struc- tural and microstructural characteristic with implications for seismicity in the upper crust, J. Struct. Geol., 103, 17-36, https://doi.org/10.1016/j.jsg.2017.09.003, 2017.

Demurtas, M., Fondriest, M., Balsamo, F., Clemenzi, L., Storti, F., Bistacchi, A., and Di Toro, G.: Structure of a normal seismogenic fault zone in carbonates: The Vado di Corno Fault, Campo Imperatore, Central Apennines (Italy), J. Struct. Geol., 90, 185-206, https://doi.org/10.1016/j.jsg.2016.08.004, 2016.

Demurtas, M., Smith, S. A. F., Prior, D. J., Spagnuolo, E., and Di Toro, G.: Development of crystallographic preferred orientation during cataclasis in low-temperature carbonate fault gouge, J. Struct. Geol., 126, 37-50, https://doi.org/10.1016/j.jsg.2019.04.015, 2019a.

Demurtas, M., Smith, S. A. F., Prior, D. J., Brenker, F. E., and Di Toro, G.: Grain size sensitive creep during simulated seismic slip in nanogranular fault gouges: constraints from Transmission Kikuchi Diffraction (TKD), J. Geophys. Res.-Solid Ea., 124, https://doi.org/10.1029/2019jb018071, 2019b.

Di Toro, G., Niemeijer, A. R., Tripoli, A., Nielsen, S., Di Felice, F., Scarlato, P., Spada, G., Alessandroni, R., Romeo, G., Di Stefano, G., Smith, S., Spagnuolo, E., and Mariano, S.: From field geology to earthquake simulation: A new state-of-the-art tool to investigate rock friction during the seismic cycle (SHIVA), Rend. Lincei, 21, 95-114, https://doi.org/10.1007/s12210-010-0097-x, 2010.

Fondriest, M., Smith, S. A. F., Candela, T., Nielsen, S. B., Mair, K., and Toro, G. Di: Mirror-like faults and power dissipation during earthquakes, Geology, 41, 1175-1178, https://doi.org/10.1130/G34641.1, 2013.

Fondriest, M., Aretusini, S., Di Toro, G., and Smith, S. A. F.: Fracturing and rock pulverization along an exhumed seismogenic fault zone in dolostones: The Foiana Fault Zone (Southern Alps, Italy), Tectonophysics, 654, 56-74, https://doi.org/10.1016/j.tecto.2015.04.015, 2015.

Fondriest, M., Balsamo, F., Bistacchi, A., Clemenzi, L., Demurtas, M., Storti, F., and Di Toro, G.: Structural Complexity and Mechanics of a Shallow Crustal Seismogenic Source (Vado di Corno Fault Zone, Italy), J. Geophys. Res.-Solid Ea., 125, 9, https://doi.org/10.1029/2019jb018926, 2020.

Green II, H. W., Shi, F., Bozhilov, K., Xia, G., and Reches, Z.: Phase transformation and nanometric flow cause extreme weakening during fault slip, Nat. Geosci., 8, 484-489, https://doi.org/10.1038/ngeo2436, 2015.

Han, R., Shimamoto, T., Ando, J., and Ree, J.-H.: Seismic slip record in carbonate-bearing fault zones: An insight from highvelocity friction experiments on siderite gouge, Geology, 35, 1131-1134, https://doi.org/10.1130/G24106A.1, 2007.

Holyoke, C. W., Kronenberg, A. K., and Newman, J.: Microstructural evolution during strain localization in dolomite aggregates, J. Struct. Geol., 69, 449-464, https://doi.org/10.1016/j.jsg.2014.04.008, 2014.

Jefferies, S. P., Holdsworth, R. E., Shimamoto, T., Takagi, H., Lloyd, G. E., and Spiers, C. J.: Origin and mechanical significance of foliated cataclastic rocks in the cores of crustal-scale faults: Examples from the Median Tectonic Line, Japan, J. Geophys. Res.-Solid Ea., 111, 1-17, https://doi.org/10.1029/2005JB004205, 2006.

Kennedy, L. A. and Logan, J. M.: The role of veining and dissolution in the evolution of fine-grained mylonites: the 
McConnell thrust, Alberta, J. Struct. Geol., 19, 785-797, https://doi.org/10.1016/S0191-8141(97)00005-9, 1997.

Kennedy, L. A. and White, J. C.: Low-temperature recrystallization in calcite: Mechanisms and consequences, Geology, 29, 1027-1030, https://doi.org/10.1130/00917613(2001)029<1027:LTRICM>2.0.CO;2, 2001.

Kushnir, A. R. L., Kennedy, L. A., Misra, S., Benson, P., and White, J. C.: The mechanical and microstructural behaviour of calcitedolomite composites: An experimental investigation, J. Struct. Geol., 70, 200-216, https://doi.org/10.1016/j.jsg.2014.12.006, 2015.

Li, T., Sui, F., Li, F., Cai, Y., and Jin, Z.: Effects of dry grinding on the structure and granularity of calcite and its polymorphic transformation into aragonite, Powder Technol., 254, 338-343, https://doi.org/10.1016/j.powtec.2014.01.043, 2014.

Lin, A.: S-C fabrics developed in cataclastic rocks from the Nojima fault zone, Japan and their implications for tectonic history, J. Struct. Geol., 23, 1167-1178, https://doi.org/10.1016/S01918141(00)00171-1, 2001

Liu, J., Walter, J. M., and Weber, K.: Fluidenhanced low-temperature plasticity of calcite marble: Microstructures and mechanisms, Geology, 30, 787-790, https://doi.org/10.1130/00917613(2002)030<0787:FELTPO>2.0.CO;2, 2002.

Logan, J. M., Friedman, M., Higgs, N., Dengo, C., and Shimamoto, T.: Experimental studies of simulated gouge and their application to studies of natural fault zones, Proceedings of Conference VIII on Analysis of Actual Fault Zones in Bedrock, U.S. Geological Survey Open-File Report 79-1239, April 1979, 305-343, 1979.

Marone, C., Raleigh, C. B., and Scholz, C. H.: Frictional behavior and constitutive modeling of simulated fault gouge, J. Geophys. Res., 95, 7007-7025, 1990.

Martinelli, G. and Plescia, P.: Mechanochemical dissociation of calcium carbonate: Laboratory data and relation to natural emissions of $\mathrm{CO}_{2}$, Phys. Earth Planet. Inter., 142, 205-214, https://doi.org/10.1016/j.pepi.2003.12.009, 2004.

Masoch, S., Fondriest, M., Preto, N., Secco, M., and Di Toro, G.: Seismic cycle recorded in cockade-bearing faults (Col de Teghime, Alpine Corsica), J. Struct. Geol., 129, 103889, https://doi.org/10.1016/j.jsg.2019.103889, 2019.

Miller, J. A., Viola, G., and Mancktelow, N. S.: Oxygen, carbon and strontium isotope constraints on the mechanisms of nappe emplacement and fluid-rock interaction along the subhorizontal Naukluft Thrust, central Namibia, J. Geol. Soc. London., 165, 739-753, https://doi.org/10.1144/0016-76492007-079, 2008.

Mitchell, T. M., Smith, S. A. F., Anders, M. H., Di Toro, G., Nielsen, S., Cavallo, A., and Beard, A. D.: Catastrophic emplacement of giant landslides aided by thermal decomposition: Heart Mountain, Wyoming, Earth Planet. Sci. Lett., 411, 199207, https://doi.org/10.1016/j.epsl.2014.10.051, 2015.

Molli, G., Cortecci, G., Vaselli, L., Ottria, G., Cortopassi, A., Dinelli, E., Mussi, M., and Barbieri, M.: Fault zone structure and fluid-rock interaction of a high angle normal fault in Carrara marble (NW Tuscany, Italy), J. Struct. Geol., 32, 1334-1348, https://doi.org/10.1016/j.jsg.2009.04.021, 2010.

Molli, G., White, J. C., Kennedy, L., and Taini, V.: Low-temperature deformation of limestone, Isola Palmaria, northern Apennine, Italy - The role of primary textures, precursory veins and in- tracrystalline deformation in localization, J. Struct. Geol., 33, 255-270, https://doi.org/10.1016/j.jsg.2010.11.015, 2011.

Monzawa, N. and Otsuki, K.: Comminution and fluidization of granular fault materials: Implications for fault slip behavior, Tectonophysics, 367, 127-143, https://doi.org/10.1016/S00401951(03)00133-1, 2003.

Niemeijer, A. R. and Spiers, C. J.: Velocity dependence of strength and healing behaviour in simulated phyllosilicatebearing fault gouge, Tectonophysics, 427, 231-253, https://doi.org/10.1016/j.tecto.2006.03.048, 2006.

Niemeijer, A., Di Toro, G., Nielsen, S., and Di Felice, F.: Frictional melting of gabbro under extreme experimental conditions of normal stress, acceleration, and sliding velocity, J. Geophys. Res.Solid Ea., 116, 1-18, https://doi.org/10.1029/2010JB008181, 2011.

Oesterling, N., Heilbronner, R., Stünitz, H., Barnhoorn, A., and Molli, G.: Strain dependent variation of microstructure and texture in naturally deformed Carrara marble, J. Struct. Geol., 29, 681-696, https://doi.org/10.1016/j.jsg.2006.10.007, 2007.

Ohl, M., Plümper, O., Chatzaras, V., Wallis, D., Vollmer, C., and Drury, M.: Mechanisms of fault mirror formation and fault healing in carbonate rocks, Earth Planet. Sci. Lett., 530, 115886, https://doi.org/10.1016/j.epsl.2019.115886, 2020.

Paterson, M. S. and Olgaard, D. L.: Rock deformation tests to large shear strains in torsion, J. Struct. Geol., 22, 1341-1358, 2000.

Pozzi, G., De Paola, N., Nielsen, S. B., Holdsworth, R. E., and Bowen, L.: A new interpretation for the nature and significance of mirror-like surfaces in experimental carbonate-hosted seismic faults, Geology, 46, 583-586, https://doi.org/10.1130/G40197.1, 2018.

Pozzi, G., De Paola, N., Holdsworth, R. E., Bowen, L., Nielsen, S. B., and Dempsey, E. D.: Coseismic ultramylonites: An investigation of nanoscale viscous flow and fault weakening during seismic slip, Earth Planet. Sci. Lett., 516, 164-175, https://doi.org/10.1016/j.epsl.2019.03.042, 2019.

Rathbun, A. P. and Marone, C.: Effect of strain localization on frictional behavior of sheared granular materials, J. Geophys. Res., 115, 1-16, https://doi.org/10.1029/2009jb006466, 2010.

Rempe, M., Smith, S., Mitchell, T., Hirose, T., and Di Toro, G.: The effect of water on strain localization in calcite fault gouge sheared at seismic slip rates, J. Struct. Geol., 97, 104-117, https://doi.org/10.1016/j.jsg.2017.02.007, 2017.

Rempe, M., Di Toro, G., Mitchell, T. M., Smith, S. A. F., Hirose, T., and Renner, J.: Influence of Effective Stress and Pore Fluid Pressure on Fault Strength and Slip Localization in Carbonate Slip Zones, J. Geophys. Res.-Sol. Ea., 125, 11, https://doi.org/10.1029/2020JB019805, 2020.

Risnes, R., Madland, M. V., Hole, M., and Kwabiah, N. K.: Water weakening of chalk - Mechanical effects of water-glycol mixtures, J. Pet. Sci. Eng., 48, 21-36, https://doi.org/10.1016/j.petrol.2005.04.004, 2005.

Røyne, A., Bisschop, J., and Dysthe, D. K.: Experimental investigation of surface energy and subcritical crack growth in calcite, J. Geophys. Res., 116, B04204, https://doi.org/10.1029/2010jb008033, 2011.

Rowe, C. D., Moore, J. C., Meneghini, F., and McKeirnan, A. W.: Large-scale pseudotachylytes and fluidized cataclasites from an ancient subduction thrust fault, Geology, 33, 937-940, https://doi.org/10.1130/G21856.1, 2005. 
Rutter, E. H.: The effects of strain-rate changes on the strength and ductility of Solenhofen limestone at low temperature and confining pressure, Int. J. Rock Mech. Min. Sci., 9, 183-189, 1972.

Rutter, E. H.: Experimental study of the influence of stress, temperature, and strain on the dynamic recrystallization of Carrara marble, J. Geophys. Res., 100, 24651, https://doi.org/10.1029/95jb02500, 1995.

Rutter, E. H., Maddock, R. H., Hall, S. H., and White, S. H.: Comparative microstructures of natural and experimentally produced clay-bearing fault gouges, Pure Appl. Geophys., 124, 330, https://doi.org/10.1007/BF00875717, 1986.

Samtani, M., Dollimore, D., and Alexander, K. S.: Comparison of dolomite decomposition kinetics with related carbonates and the effect of procedural variables on its kinetic parameters, Thermochim. Acta, 393, 135-145, 2002.

Sarnes, B. and Schrüfer, E.: Determination of the time behaviour of thermocouples for sensor speedup and medium supervision, Proc. Est. Acad. Sci. Eng., 13, 295-309, 2007.

Schmid, S. M., Paterson, M. S., and Boland, J. N.: High temperature flow and dynamic recrystallization in Carrara marble, Tectonophysics, 65, 245-280, 1980.

Schmid, S. M., Panozzo, R., and Bauer, S.: Simple shear experiments on calcite rocks: rheology and microfabric, J. Struct. Geol., 9, 747-778, https://doi.org/10.1016/01918141(87)90157-X, 1987.

Sibson, R. H.: Conditions for fault-valve behaviour, in: Deformation Mechanisms, Rheology and Tectonics, edited by Knipe, R. J. and Rutter, E. H., Geological Society London, Special Publication, 15-28, 1990.

Smeraglia, L., Billi, A., Carminati, E., Cavallo, A., and Doglioni, C.: Field- to nano-scale evidence for weakening mechanisms along the fault of the 2016 Amatrice and Norcia earthquakes, Italy, Tectonophysics, 712-713, 156-169, https://doi.org/10.1016/j.tecto.2017.05.014, 2017.

Snoke, A. W., Tullis, J., and Todd, V. R.: Fault-Related Rocks: a Photographic Atlas, Princeton Univ. Press, Princeton, N.J., 1998.

Smith, S. A. F., Di Toro, G., Kim, S., Ree, J.-H., Nielsen, S. B., Billi, A., and Spiess, R.: Coseismic recrystallization during shallow earthquake slip, Geology, 41, 63-66, https://doi.org/10.1130/G33588.1, 2013.

Smith, S. A. F., Nielsen, S., and Di Toro, G.: Strain localization and the onset of dynamic weakening in calcite fault gouge, Earth Planet. Sci. Lett., 413, 25-36, https://doi.org/10.1016/j.epsl.2014.12.043, 2015.

Smith, S. A. F., Griffiths, J. R., Fondriest, M., and Di Toro, G.: "Coseismic Foliations" in Gouge and Cataclasite: Experimental Observations and Consequences for Interpreting the Fault Rock Record, in: Fault Zone Dynamic Processes: Evolution of Fault Properties During Seismic Rupture, edited by: Thomas, M. Y., Mitchell, T. M., and Bhat, H. S., Geophysical Monograph, Wiley Online Library, 81-102, 2017.
Tesei, T., Collettini, C., Barchi, M. R., Carpenter, B. M., and Di Stefano, G.: Heterogeneous strength and fault zone complexity of carbonate-bearing thrusts with possible implications for seismicity, Earth Planet. Sci. Lett., 408, 307-318, https://doi.org/10.1016/j.eps1.2014.10.021, 2014.

Tesei, T., Carpenter, B. M., Giorgetti, C., Scuderi, M. M., Sagy, A., Scarlato, P., and Collettini, C.: Friction and scale-dependent deformation processes of large experimental carbonate faults, J. Struct. Geol., 100, 12-23, https://doi.org/10.1016/j.jsg.2017.05.008, 2017.

Trouw, R. A., Passchier, C. W., and Wiersma, D. J.: Atlas of Mylonites-and related microstructures, Springer Science \& Business Media, Berlin, 2009.

Ungár, T.: Microstructural parameters from X-ray diffraction peak broadening, Scr. Mater., 51, 777-781, https://doi.org/10.1016/j.scriptamat.2004.05.007, 2004.

Verberne, B. A., Spiers, C. J., Niemeijer, A. R., de Bresser, J. H. P., de Winter, D. A. M., and Plümper, O.: Frictional properties and microstructure of calcite-rock fault gouges sheared at sub-seismic velocites, Pure Appl. Geophys., 31, 1-45, https://doi.org/10.1007/s00024-013-0760-0, 2014.

Verberne, B. A., Chen, J., Niemeijer, A. R., De Bresser, J. H. P., Pennock, G. M., Drury, M. R., and Spiers, C. J.: Microscale cavitation as a mechanism for nucleating earthquakes at the base of the seismogenic zone, Nat. Commun., 8, 1, https://doi.org/10.1038/s41467-017-01843-3, 2017.

Viola, G., Mancktelow, N. S., and Miller, J. A.: Cyclic frictionalviscous slip oscillations along the base of an advancing nappe complex: Insights into brittle-ductile nappe emplacement mechanisms from the Naukluft Nappe Complex, central Namibia, Tectonics, 25, 1-20, https://doi.org/10.1029/2005TC001939, 2006.

Violay, M. E. S., Nielsen, S. B., Gibert, B., Spagnuolo, E., Cavallo, A., Azais, P., Vinciguerra, S. C., and Di Toro, G.: Effect of water on the frictional behavior of cohesive rocks during earthquakes, Geology, 42, 27-30, https://doi.org/10.1130/G34916.1, 2014.

Wallis, D., Phillips, R. J., and Lloyd, G. E.: Fault weakening across the frictional-viscous transition zone, Karakoram Fault Zone, NW Himalaya, Tectonics, 32, 1227-1246, https://doi.org/10.1002/tect.20076, 2013.

Weeks, J. D. and Tullis, T. E.: Frictional sliding of dolomite: A variation in constitutive behavior, J. Geophys. Res., 90, 7821-7826, https://doi.org/10.1029/JB090iB09p07821, 1985.

Williams, J. C.: The segregation of particulate materials, A review, Powder Technology 15, 245-251, https://doi.org/10.1016/00325910(76)80053-8, 1976. 